\title{
Blue SAPPHIRES from MOgoK, Myanmar: A Gemological Review
}

Wasura Soonthorntantikul, Ungkhana Atikarnsakul, and Wim Vertriest

Burmese sapphires are among the most coveted colored gemstones in the world. The historical importance of this source and the fine quality of its high-grade material contribute to the legendary status of these gems. Since Mogok is such a long-known source, there are many classic studies available, but modern analytical data are often missing or not up to current standards. This article summarizes the characteristics of Burmese sapphires, including standard gemological properties, inclusion observations, and spectroscopic and trace element analyses. This information was collected from hundreds of blue sapphires that GIA's field gemologists sampled while visiting different mining regions in Mogok over the past decade. Our observations indicate that these sapphires show a wide range of blue color intensities but very consistent inclusion scenes. Trace element chemistry did not show any significant differences between various regions apart from a wider range of Fe concentrations in sapphires from north of Mogok. Rare observations such as orange fluorescence and unusual FTIR spectra can be attributed to the chemical compositions of the sapphires.

M ogok is the most legendary gemstone source in Myanmar; its fabled rubies have been highly desired for centuries. Perhaps equally sought-after by connoisseurs but less known to the general public are its blue sapphires (figure 1). Mogok is one of the oldest sapphire sources, but its sapphires have always faced challenges in gemological circles. Their beauty was often not acknowledged in older days, but this changed dramatically in recent decades. In light of the increasing demand for origin determination services, separating blue sapphire sources has become important for gemological laboratories. Collecting reliable samples had been extremely challenging due to limited access to the mines and the rarity of blue sapphire in Mogok. This paper aims to summarize the current knowledge of Mogok sapphires based on extensive gemological analysis of samples collected during field expeditions in the last decade, combined with data available in the gemological literature.

\section{INTRODUCTION TO MOGOK SAPPHIRES}

Myanmar and Mogok. The Asian country of Myanmar, formerly known as Burma, is located on the

See end of article for About the Authors and Acknowledgments.

Gems \& Gemologr, Vol. 57, No. 4, pp. 292-317,

http://dx.doi.org/10.5741/GEMS.57.4.292

(C) 2021 Gemological Institute of America crossroads between Southeast Asia, the Indian Subcontinent, and China. From 200 BCE to $800 \mathrm{CE}$, the land was controlled by a group of city-states, often

\section{In Brief}

- Mogok sapphires have been treasured for centuries, yet modern gemological studies are scarce and most rely on limited samples. This study summarizes all gemological data for Burmese sapphires collected in the field by GIA gemologists.

- The most common inclusions are silk and twin planes, and their appearance can potentially distinguish them from other sources.

- Fourier-transform infrared (FTIR) spectra of the studied Mogok sapphires frequently display hydroxyl-related mineral features, while UV-Vis-NIR spectra commonly show a pattern typical for metamorphic deposits.

- Trace element chemistry analyses by LA-ICP-MS did not reveal any significant differences between the sapphire-producing zones in the Mogok area. The trace element chemistry of Burmese sapphires also shows overlap with other metamorphic sapphire sources. Origin determination still relies heavily on observation of inclusions.

referred to as the Pyu city-states. This state structure was replaced by a line of larger kingdoms after the Burmans drove out the Pyu in the ninth century. 


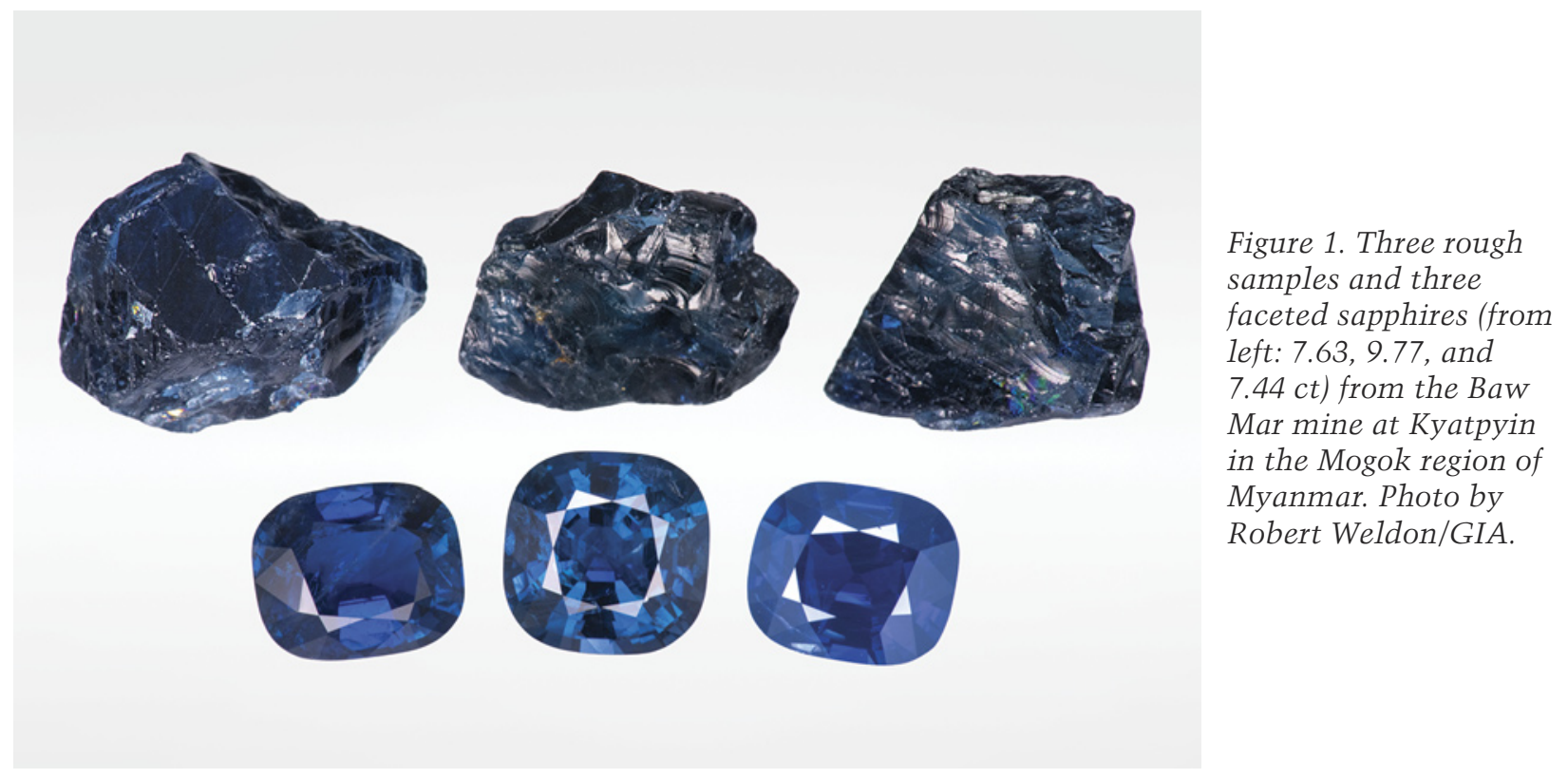

Among the earliest was the Pagan Kingdom, which laid the foundation for the nation that later became modern-day Myanmar. This can be seen as the foundation of the Burmese language and culture, including the adoption of Theravada Buddhism as the state religion. The ancient capital, now referred to as Bagan and designated as a UNESCO World Heritage Site, is one of the main tourism destinations in the country. This kingdom eventually fell to Mongol invasions, after which it took centuries to recover and reunify the nation under the Toungoo Dynasty in the mid-sixteenth century. In 1752, it was replaced by the Konbaung Dynasty, which continued the administrative reforms set out by the previous rulers. Initially, the Konbaung rulers tried to resist increasing pressure from European colonial powers. In 1885, after they lost the third Anglo-Burmese war, Burma was completely annexed into the British Empire.

The earliest writings from European explorers mentioned the close connection between the different Burmese empires and their vast gem resources (Hughes et al., 2017; Temple, 1928; Penzer, 1937). Later explorers with better-documented journals provided detailed firsthand accounts of the "markets stocked in rubies and sapphires" (d'Amato, 1833; Luard, 1926-1927). Evidently, the British colonists took great interest in all natural resources, including gemstones. During the annexation, large-scale operations were leased out to mining firms for the first time. These were most successful in the late 1890s and early 1900s. World War I shifted economic priorities, and the importance of gemstone mining sub- sided (Brown, 1927; Hughes et al., 2017). European control was only briefly interrupted during World War II when Japanese forces took control of Burma. Colonial rule lasted until 1948, when Burma gained its independence from the British Empire.

In 1962, only 14 years after the country gained its independence, the military regime took control of the state. The military junta, also referred to as Tatmadaw, changed the name of the country to Myanmar in 1989. They refused to give up their total power until 2011, when the ruling military party was reformed. However, the military kept tight control on the young democracy, and after the 2020 elections it once again took control of the country in a new coup d'état in February 2021.

The Mogok region is located in central Myanmar, around $120 \mathrm{~km}$ northeast of Mandalay (figure 2). The area is located on the western side of the Shan Plateau and flanked by the Ayeyarwady (Irrawaddy) River to the west. The rugged terrain is characterized by steep hills and numerous streams cutting through. The main city is located at an elevation of $1100 \mathrm{~m}$, but the surrounding mountains can reach nearly $2300 \mathrm{~m}$. Due to high rainfall and warm summers, vegetation is abundant and the jungle quickly reclaims abandoned areas. During winter, the temperatures at higher elevations can dip below the freezing point.

The name "Mogok" is used to describe many things and can lead to some confusion. It is important to know which "Mogok" is being referred to. The town of Mogok is where much of the gem trading ac- 

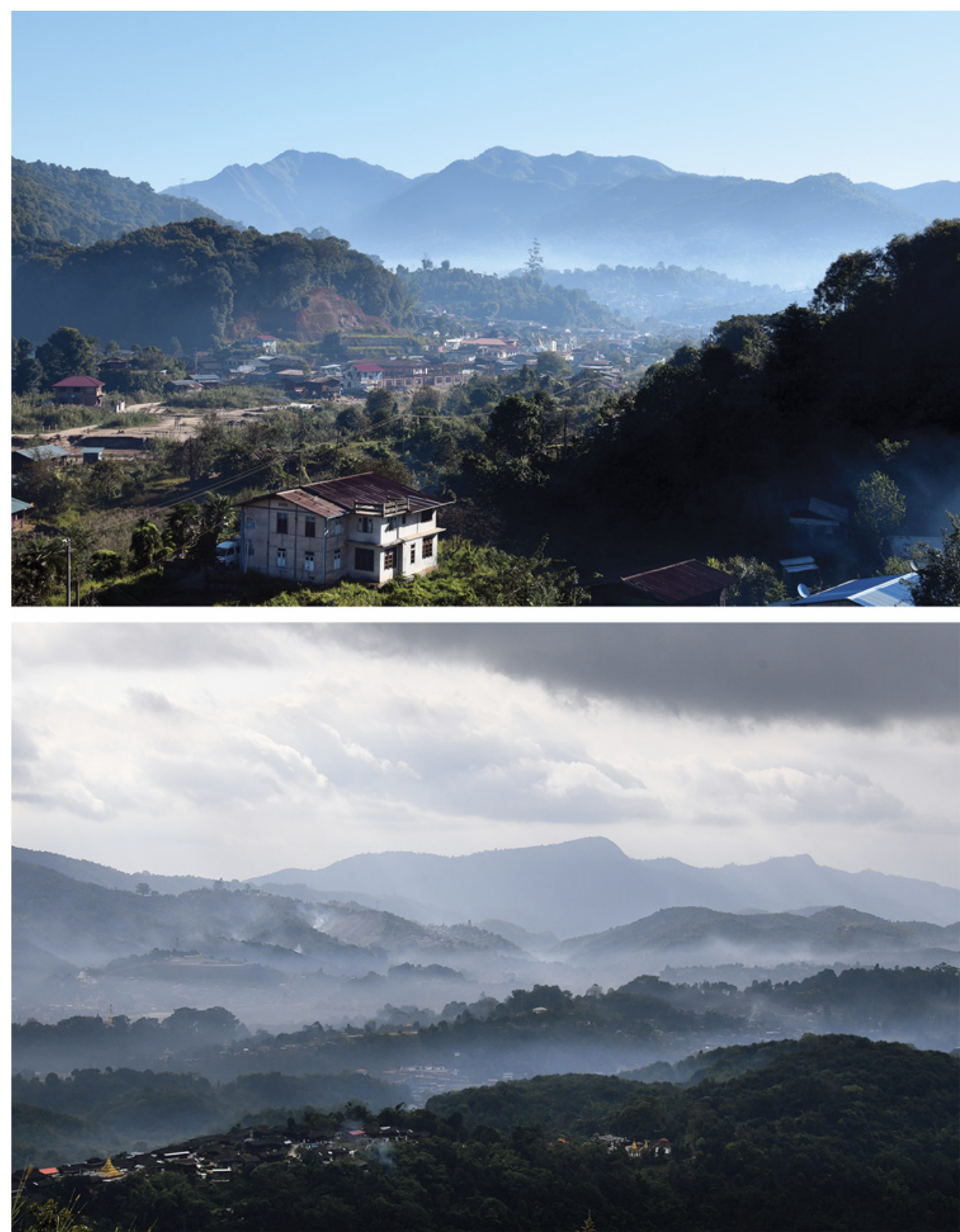

Figure 2. Mogok Valley just after sunrise. Mist fills the valleys and mixes with smoke from the wood fires used to cook breakfast and heat homes, especially during the winter months. Photos by Wim Vertriest. tivity takes place and is near many of the historical gem mines. Mogok township is the administrative area comprising Mogok city, Kyatpin, and other surrounding towns. More than 170,000 people live in the township. The Mogok Stone Tract, a term introduced by the British administration, does include the Mogok township but stretches much farther north.

The Mogok administrative area consists of different settlements. Figure 3 covers the extent of the Mogok township and indicates some notable towns. The main population concentrations are in the cities of Mogok and Kyatpin, which lie in the heart of the gemstone mining areas. In the rest of this article, the term "Mogok" refers to the wider area, not exclusively to the town or a single mine.

Foreigners cannot visit freely and must have permission from the appropriate authorities and be accompanied by a government-approved guide at all times. Mogok has been subject to sudden closures and has always been difficult to enter. Even when all paperwork has been approved, permits can be retracted at the last minute.

Mogok Sapphire. While Mogok is commonly associated with rubies, its variety of gems is unmatched. Apart from ruby, the other important stones are 


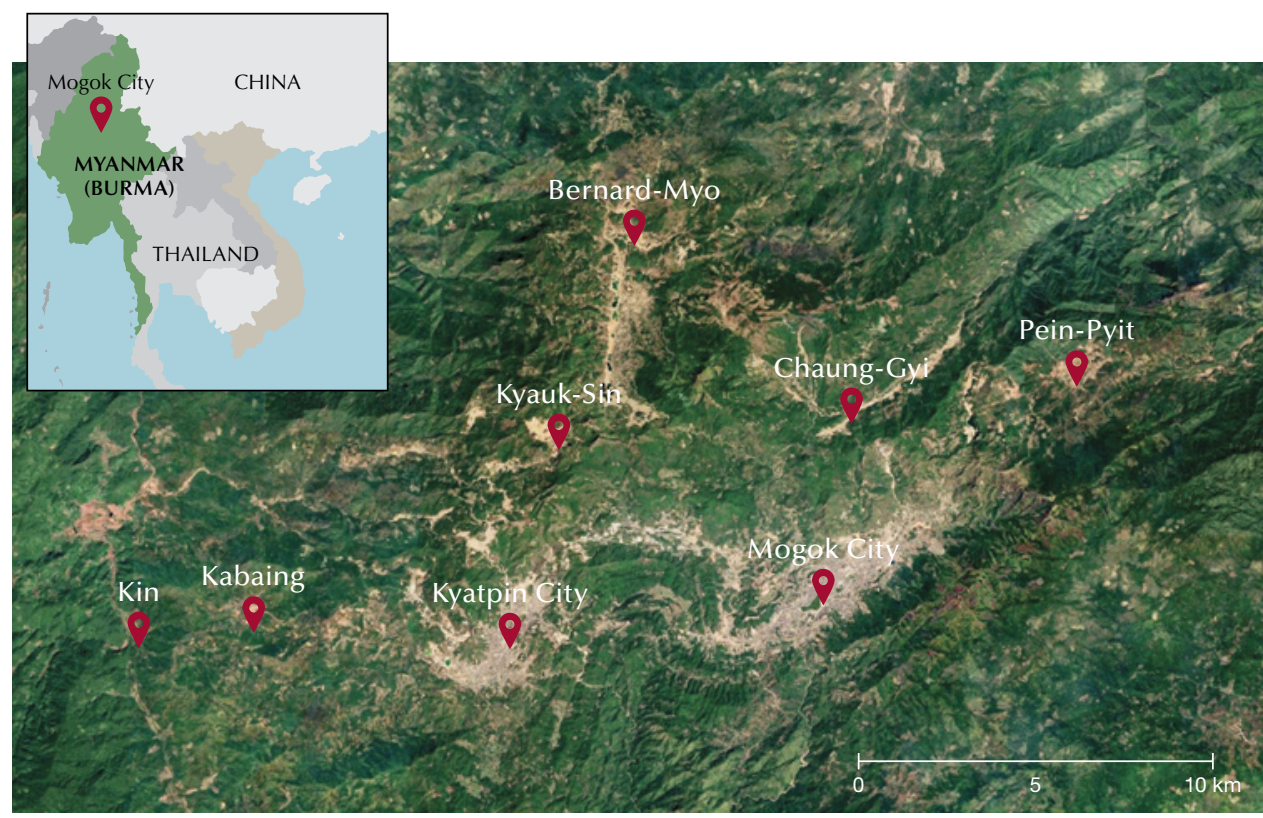

Figure 3. Map of the Mogok township and some nearby towns. Gem mines extend to the north slope of the mountains north of Bernard-Myo and also to the south.

spinel, sapphire, and peridot. Rare collector minerals such as painite and johachidolite have been discovered there. Mogok's finest sapphires are of exceptional quality, and a Burmese origin is considered one of the most desired localities, surpassed only by Kashmir (Hughes et al., 2017). Today, Burmese sapphire is held in high esteem by the trade, but this was not always the case.

At the end of the nineteenth century, Burmese sapphires were considered too dark (Streeter, 1892). Only in the middle of the twentieth century did these stones acquire the reputation they hold today. Smith (1972) wrote that no other source produced sapphires as superb as Burma's. Brown and Dey (1955) took a more modest approach: "It has been stated that
Burmese sapphires as a whole are usually too dark for general approval, but this is quite incorrect; next to the Kashmir sapphires they are unsurpassed."

As with all origins, only some of the stones recovered have the desired color, size, and clarity, and thus origin is not synonymous with quality. The best Mogok sapphires have a saturated, rich, intense blue color, sometimes with a light violet component. But Mogok sapphires are by no means restricted to these typical rich blue colors. A wide range of tone and saturation in blue color is found, from pale icy blue and delicate periwinkle to dark navy blue (figure 4). Fine star sapphires have also been reported from the western area, near Kin (Hughes and Win, 1995). While Mogok rubies are much more common in the trade

Figure 4. Mogok sapphires are traditionally known for darker blue colors, but in reality a vast range of blue tones and saturations can be found in the mines around Mogok, as shown in this image. Photo by Robert Weldon/GIA.

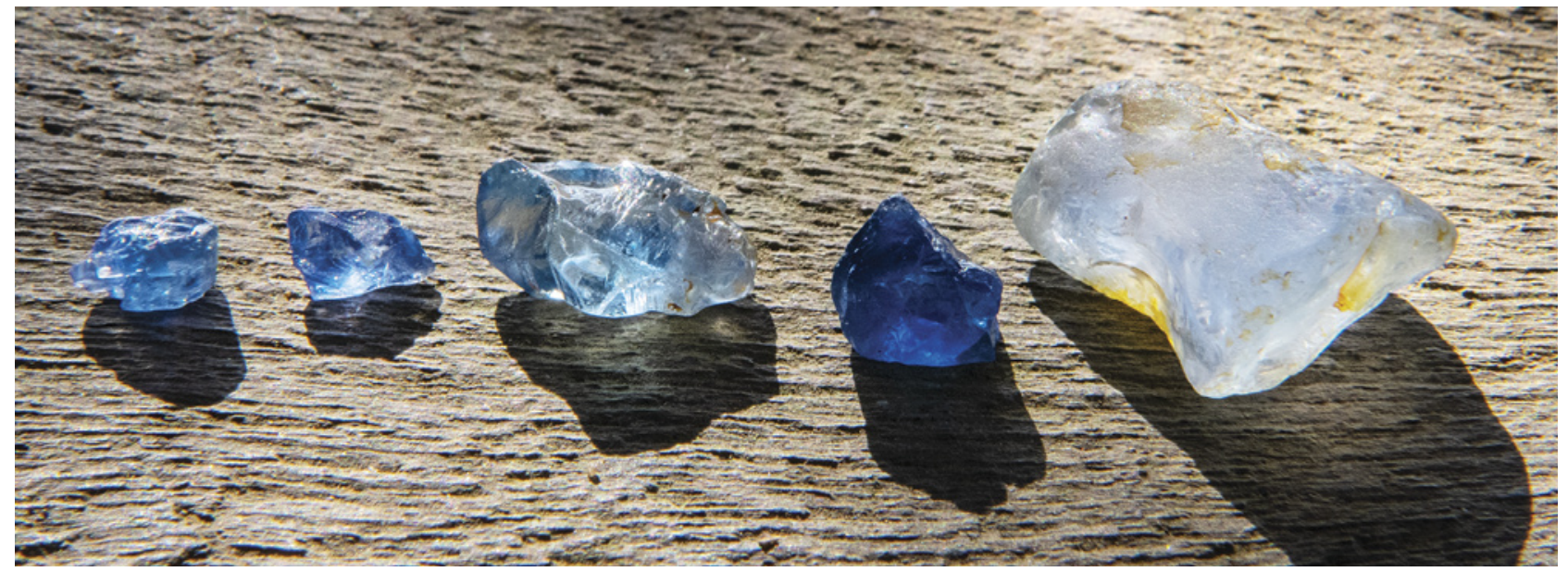




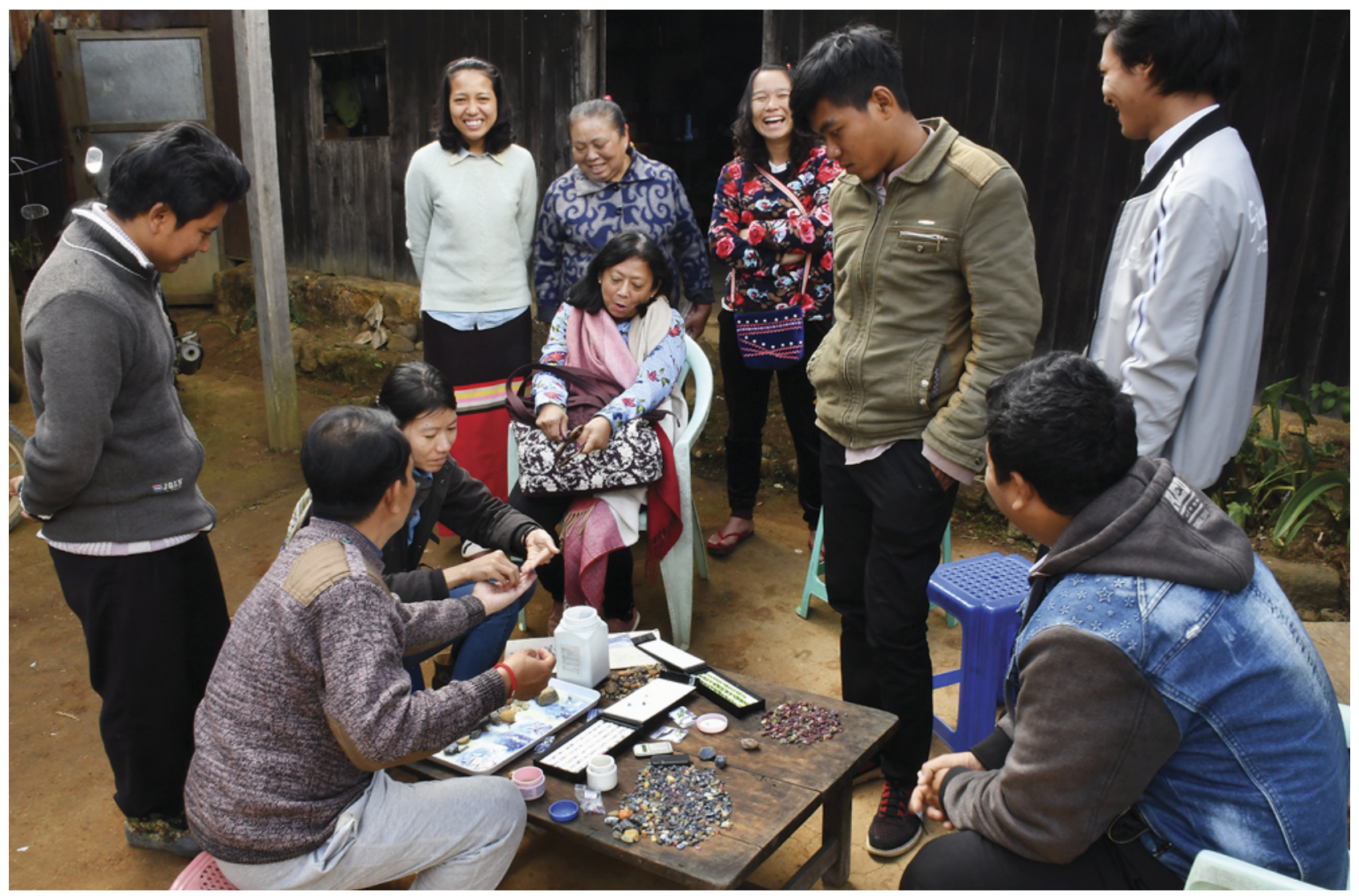

Figure 5. An invitation for a cup of tea quickly turned into a sapphire extravaganza in this gem trader's front yard, near the town of Bernard-Myo in northern Mogok. Blue and fancy sapphires were shown, and a lively debate about the blue gems lasted for nearly an hour. Photo by Wim Vertriest.

than their blue cousins, the size of Burmese sapphires is one of the reasons for their fame. Finished gems larger than 100 carats have been documented, and gray-blue corundum crystals weighing several kilograms have been recovered, although the latter were not facetable.

Blue sapphires are found all over the Mogok area, but the town of Pein-Pyit and the Chaung-Gyi Valley to the northeast of Mogok city in particular are known to produce a blue sapphire of various intensities and tones. The northern town of Bernard-Myo and the north-south trending valley it lies in have a thriving sapphire mining and trading scene next to the large peridot mines found in this area. The area to the west and northwest of Kyatpin, with main centers in Baw Mar and Kyauk-Sin, hosts some of the largest mines. Many smaller mines are in the Thurein-Thaung/Yadana-Kaday-Kadar area a bit farther south. Blue sapphires are also found on the Mogok Stone Tract's western border in river gravels near the towns of Kin and Kabaing. The large secondary deposits in the lower parts of the valleys once held significant volumes of sapphire that washed down from the surrounding mountains, but most of these are now exhausted.

Sapphire dealers in Mogok pay very close attention to the source of the rough (figure 5). It is believed that sapphires from western Mogok maintain their rich blue color in various orientations, while those from the eastern parts may take a greenish tint when the c-axis is not precisely perpendicular to the table (Hughes and Win, 1995). Some sapphires from Bernard-Myo have a stronger violet component, making them too dark, or a strong green component (Halford-Watkins, 1935). However, these are anecdotal observations from traders, and some of these views can be quite dated. There have been no extensive studies to back them up.

\section{GEOLOGY AND MINING OF THE MOGOK SAPPHIRE DEPOSITS}

Regional Geology of Mogok. Due to limited access, complicated geological history, degree of weathering, 
and thick vegetation cover, the local geology of Mogok is not well understood. Only recently have advanced geological studies taken place, but they are focused on larger scale structures and not directly on gem-forming processes.

The area is part of the Mogok Metamorphic Belt, a geological feature that extends over $1500 \mathrm{~km}$ from the Andaman Sea in the south to the edge of the Eastern Himalayas in the north. Marbles metamorphosed under high amphibolite- and granulite-facies conditions are the dominant lithology in this belt, but a variety of high-grade metamorphic and intrusive rocks are found (figure 6).

In the Mogok and Kyatpin valleys, where gem minerals are most common, the marbles have been intruded by charnockite and syenite intrusions, forming sills. The center of the valley consists of this unit and stretches WSW-ENE, dipping to the south. Most intrusions are concordant with the marble layering (figure 6). While the exact age of the marble is unclear, it formed in the Tethys Ocean, which completely disappeared with the collision of the Indian Subcontinent with Asia (Iyer, 1953; Oo, 2011; Searle et al., 2007; Zahirovic et al., 2012). The syenite intrusions have been dated, but interpretation of these ages is not conclusive since some of them might have been reset in later stages. Most dates place the intrusions in the early Jurassic period (170-163 Ma), although others point to a younger age (67-22 Ma). These younger dates overlap with the intense metamorphism associated with the formation of the Himalayas and have probably been overprinted (Searle et al., 2020).

Field observations have determined the presence of several sills, with Taung-Met syenite being the

Figure 6. The geology in Mogok is dominated by a WSW-ENE trending marble layer that dips to the south. In between these marbles are numerous syenite and charnockite layers. Toward the south is a suite of gem-barren metamorphic rocks. The western border of Mogok is defined by the Kabaing granite, which has several pegmatiterelated gem deposits associated with it. From Searle et al. (2020).

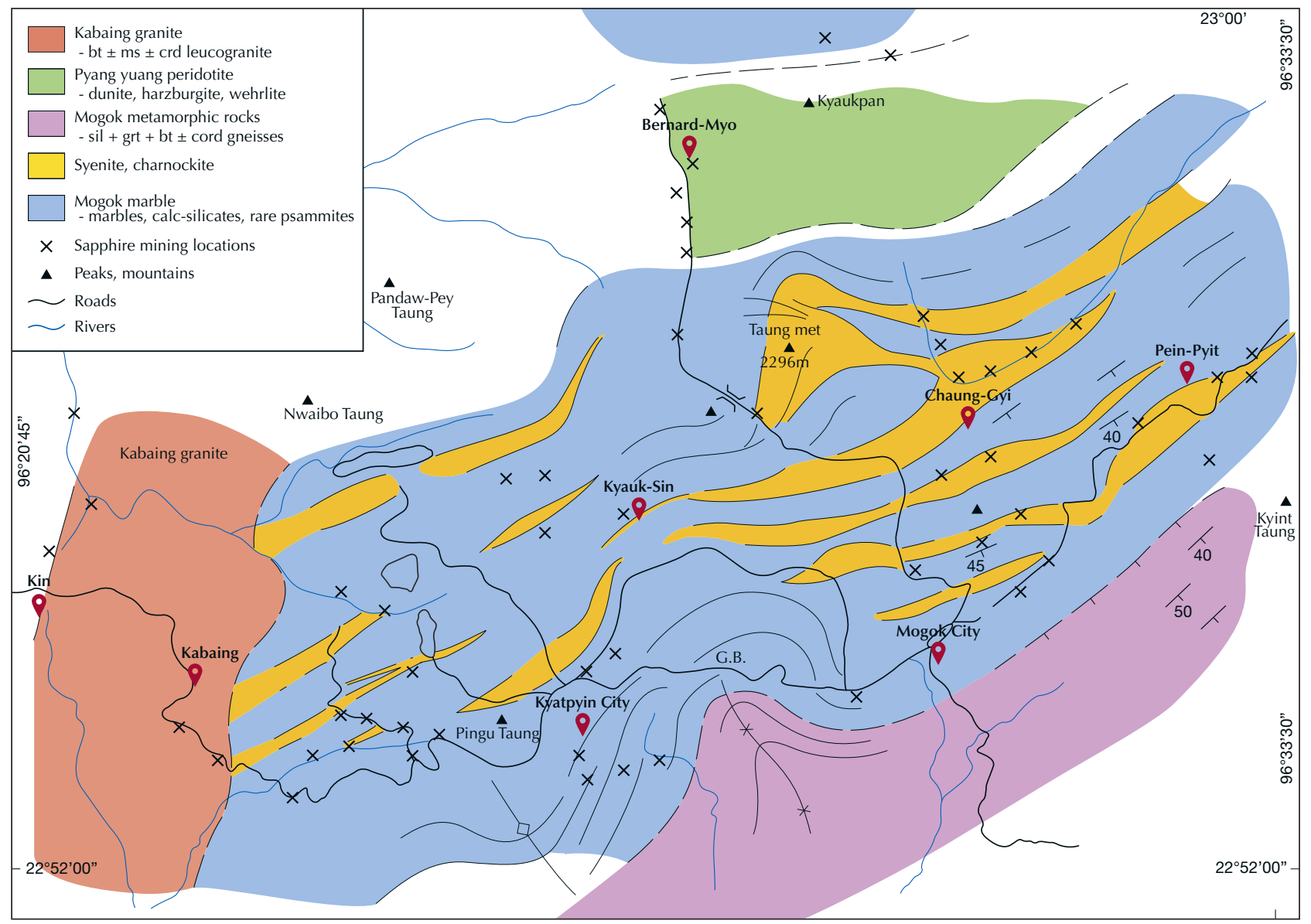


most obvious with a thickness of $400 \mathrm{~m}$. This intrusion is among the most resistant rocks and stands out in relief as the hill range north of Mogok and Kyatpin cities and includes the highest point in the Mogok area (Taung-Met-Taung Mountain; again, see figure 6). The syenite-charnockite rocks can have variable mineralogical components, but field observations suggested that the syenites, in combination with marbles and skarn, are more closely related to gem formation than the charnockites (Searle et al., 2020). Nevertheless, charnockites have been described as the source for sapphire and other gem mineralizations in Sri Lanka (Rupasinghe and Dissanayake, 1985).

The intrusions developed extensive calc-silicate skarns in the marble. The increased heat from the hot intrusions combined with the low Si-activity in them created the right conditions for corundum formation. It is in these skarn zones, limited to a structural distance of $1-2 \mathrm{~km}$ from the intrusion, that most rubies and sapphires are found. Field observations indicate that sapphire typically forms closer to the intrusions (Searle et al., 2020).

In the immediate vicinity of the intrusions, metasomatized zones form around them. This metasomatization results in the formation of mineralized zones that are often rich in mica but might also contain sodalite, lazurite, and others, depending on the local conditions (Searle et al., 2020).

This means that Mogok was subjected to a localized metamorphic event related to the intrusions of the charnockite-syenites, probably in the early Jurassic period. The entire region underwent granulite-facies metamorphism in the late Cretaceous to the early Miocene.

Intrusions of leucogranite and associated pegmatites that are most likely related to the large Kabaing granite intrusion to the west are also found (Gardiner et al., 2014, 2016; Iyer, 1953; Themelis, 2008). These are also related to gem mineralization but are more likely the source of pegmatite-related gemstones (topaz, aquamarine, etc.) that appear to be more common toward the west of Mogok. These intrusions are much younger and only intruded after peak metamorphic conditions passed (22-18 Ma) (Searle et al., 2020). In western Mogok, they overlap alongside the older syenite intrusions, but their interaction might have triggered the formation of new minerals.

Toward the north, there is a large ultramafic body. There is still an ongoing debate whether this intruded during later metamorphism or represents an ophiolitic mantle rock (Searle et al., 2017; Thu, 2007).
Geology of Mogok Sapphire Deposits. While ruby and spinel from Mogok formed in relatively pure marbles, the formation of sapphire is less understood and likely more complicated (Garnier et al., 2008). Most studies agree that the intrusions played a significant role in the formation of blue corundum in Mogok. Still, there is little clarity whether these intrusions are directly responsible for sapphire mineralization or are just one of the factors that played a role. Field observations have shown a strong link between the distribution of gem corundum and the syenite/charnockite intrusions, although the gems themselves only formed during later metamorphism (Searle et al., 2020). Many of the intrusions were Sipoor, which meant that they had the capacity to leach silicon from the host rocks, leaving an environment enriched in aluminum, which is required for corundum formation. The reverse process can also occur, where silicon is removed from the intrusion by the host rock. This way, the intrusion can be desilicated and relatively enriched in $\mathrm{Al}$, thus forming a suitable environment for corundum. This rock is sometimes referred to as plumasite (Giuliani et al., 2014). Some studies found strong indicators that the sapphires found in the syenite intrusions might be xenocrysts. In other words, they did not form in the syenitic magma but rather were picked up and brought to the surface (Turnier and Harlow, 2017). Given the complex geology of the Mogok gem area, we cannot exclude the possibility that there are multiple types of sapphire-forming processes responsible for its wealth of blue sapphire.

While the geological formation of Mogok sapphire is not yet fully understood, it is obviously unrelated to alkali basalt extrusions. Some of the richest sapphire deposits on our planet are associated with basalts, and these gems are often referred to as basaltic or magmatic. Typical localities are Thailand, Nigeria, and Australia. They share similar gemological and mineralogical characteristics, which sets them apart from the second group of sapphires, known as metamorphic. These metamorphic sapphires are found mainly in Sri Lanka and Madagascar, as well as Mogok. While the geological formation of these sources is not well understood, they do share sufficient spectroscopic and gemological similarities to group them together. These similarities make it challenging to determine the exact geographic origin of metamorphic sapphires.

Mining Techniques. Mogok's sapphires are mainly mined in secondary deposits. In these deposits, crystals 


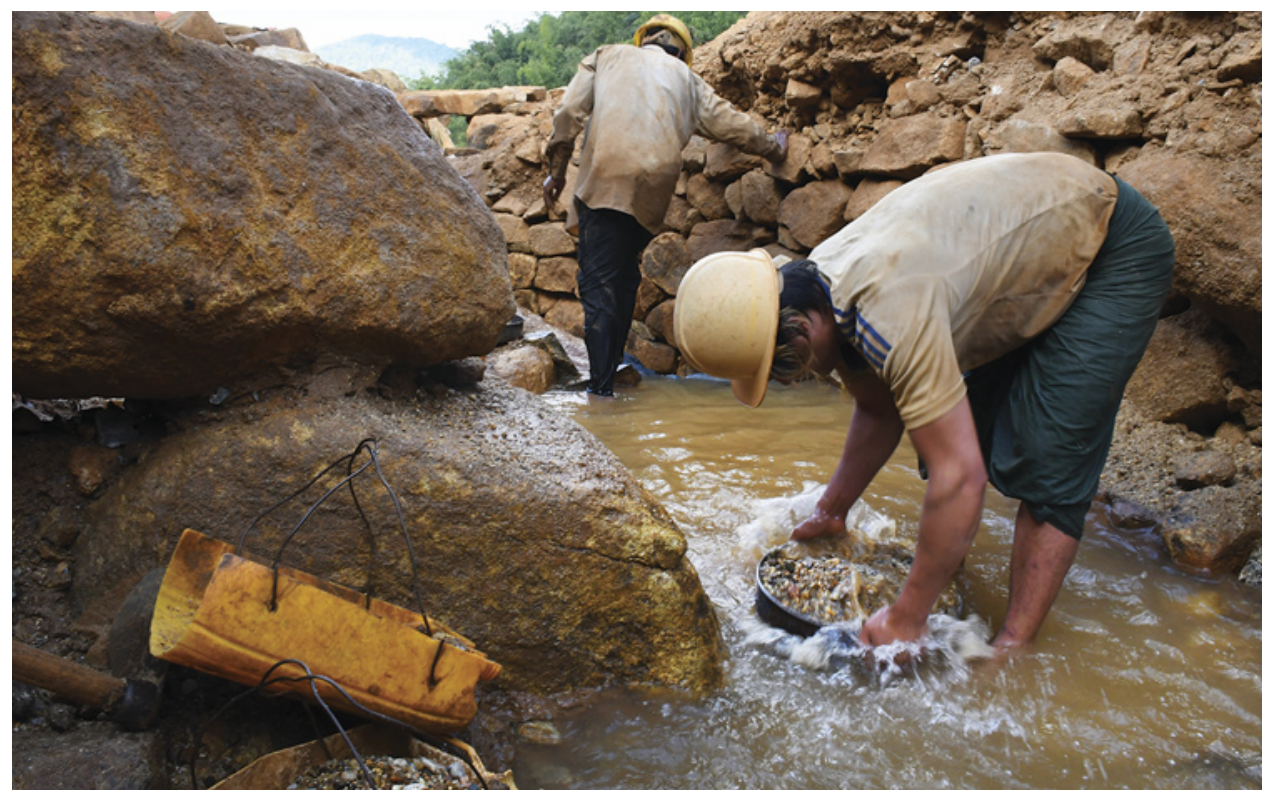

Figure 7. A miner washes byon that was trapped between large boulders. The use of simple techniques allows them to access areas that cannot be reached with heavy equipment. In the far western part of Mogok, near the Kin Valley, miners find blue sapphire and spinel mostly in these gem-rich gravels. Photo by Wim Vertriest.

have been released from the host rock. Due to various processes, often related to transport in water, the heaviest minerals are concentrated. This concentrate is called byon in Myanmar and contains a mixture of several minerals, including corundum, spinel, tourmaline, and topaz, depending on the location (figure 7).

Gemstone mining has a long tradition in Mogok, and several mining methods are used for sapphire (Hughes et al., 2017). The first type is called twin-lon, where a narrow shaft is sunk into the ground to reach the byon. Once the byon is reached, horizontal tunnels branch out to remove as much valuable material as possible. This system is comparable to traditional gem mining in many parts of the world, although the scale is often smaller. Since flooding is a serious risk, this method is often limited to the dry season. The second type is the hmyaw-dwin method, a form of hillside open-pit mining (figure 8). Water is used to loosen up and wash away mud and light minerals, leaving behind heavier crystals such as corundum and spinel. This concentrate is then washed. Since this technique uses a lot of water, it is preferred in the wet season.

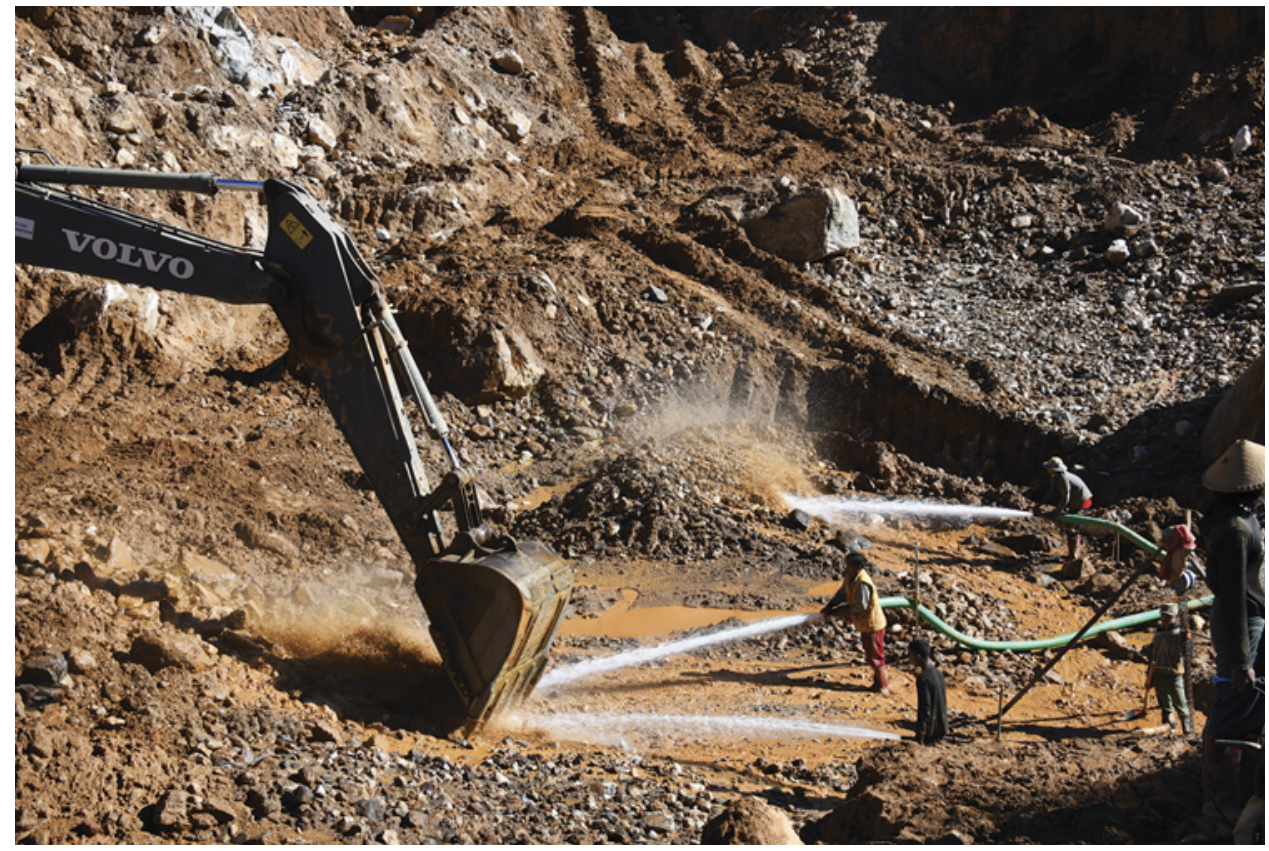

Figure 8. This modern hmyaw-dwin mine combines high-pressure water jets with an excavator. The water breaks up muddy areas, and the excavator removes large, worthless boulders and exposes fresh ground. The muddy water carries the smaller gravel and gemstones down to a gravel pump. This slurry is pumped to a washing plant, where the gems are separated from other materials. Photo by Wim Vertriest. 


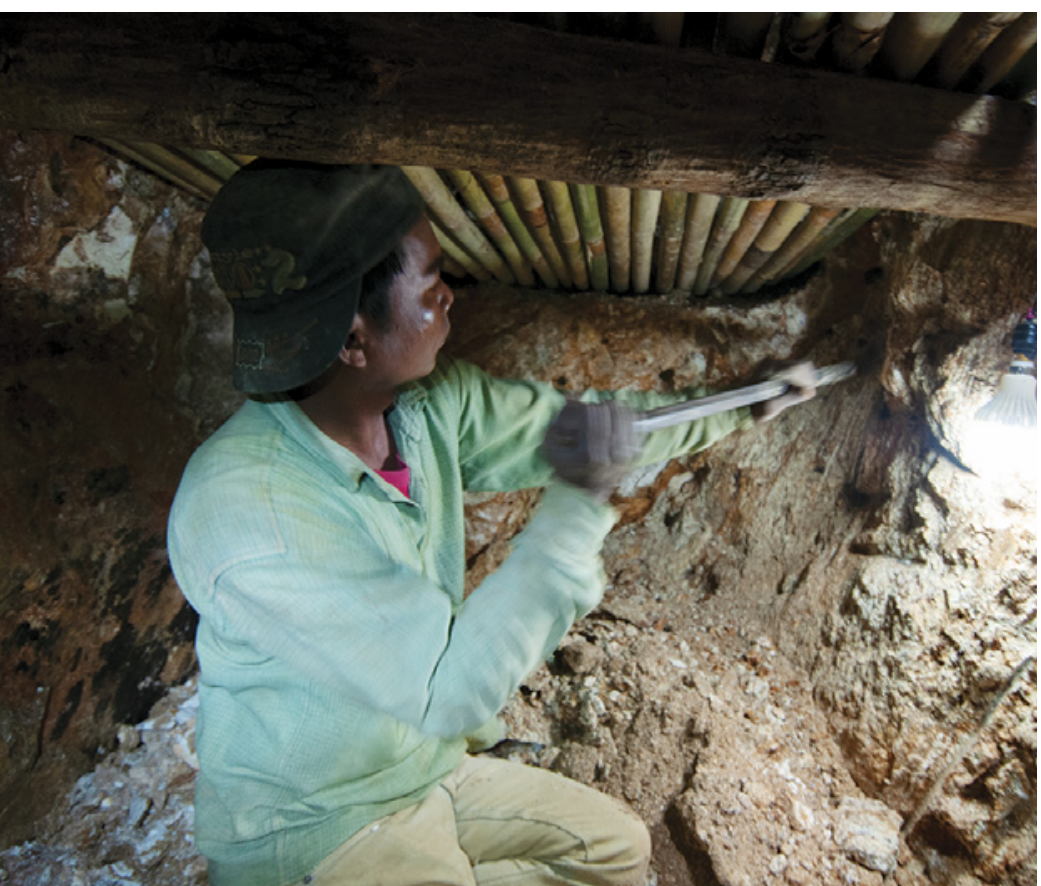

Figure 9. There are a few sapphire mines in Mogok where people extract the blue gems directly from the host rock. Following underground tunnels, they trace gem-rich zones. In many places, the rock is fairly weathered and manual tools are sufficient. On rarer occasions, blasting is required in the sapphire mines. Photo by Wim Vertriest.

Cave mining, or lu-dwin, is also common in Mogok but is mainly used for spinel and ruby since they form directly in the marble that hosts the caves. Sapphire formation is not directly linked to the marble formation; as a result, the blue gems are much less common in cave deposits.

Hard-rock mining has become more common in Mogok since most of the secondary deposits are becoming exhausted. Several sapphire mining operations have switched to this technique, although they are not comparable in size with the massive ruby operations that work primary deposits in deep tunnels. This method follows gem-rich zones through the rock and excavates them. Explosives are often required to blast through the rock in the ruby mines, but most sapphire-hosting rocks are so weathered that the gems can be removed manually, without the use of heavy equipment (figure 9). The gem-rich rocks are brought to the surface and further processed to release the gems from their matrix. Even the largest operations working in the primary deposits rely heavily on manual labor in places where gems are more abundant. Removal of overburden or barren rock is often done with heavy equipment such as excavators.

\section{MATERIALS AND METHODS}

Blue sapphires included in this study were collected from different areas in the Mogok Stone Tract by GIA field gemologists during expeditions between 2014 and 2019 (figure 10). The stones were separated into groups based on their mining area. This should allow us to see any variations based on location and to potentially test claims made by traders. While this selection covers most of the important areas, we acknowledge that not every sapphire mine in Mogok is represented. Nevertheless, all areas that are locally known to produce significant quantities of gem-quality sapphire are included in this study.

A total of 248 Mogok samples were separated into six groups based on geographic mining location in the Mogok Stone Tract area (figure 3): 21 from North (Bernard-Myo area), 32 from Northeast (Chaung-Gyi Valley), 22 from East (Pein-Pyit village and Hta-YanSho mine), 83 from Northwest (Baw Mar and KyaukSin mines), 40 from West (Yadanar-Kaday-Kadar, Thurein-Thaung, Man-Taw-Tin, Kyauk-Tya-That, and Baw-Lon-Gyi mines, located between Kabaing and Kyatpin), and 50 from Far West (Kin Valley) (table 1).

These samples were studied in three forms: 230 rough samples with one or more polished surface windows, to focus on inclusions; 12 optical wafer samples

Figure 10. GIA field gemologists inspect a parcel of small blue sapphires in the northern part of Mogok, near the village of Chaung-Gyi. These samples were classified as E-type since they were purchased from a trader in the town. Photo by Wim Vertriest.

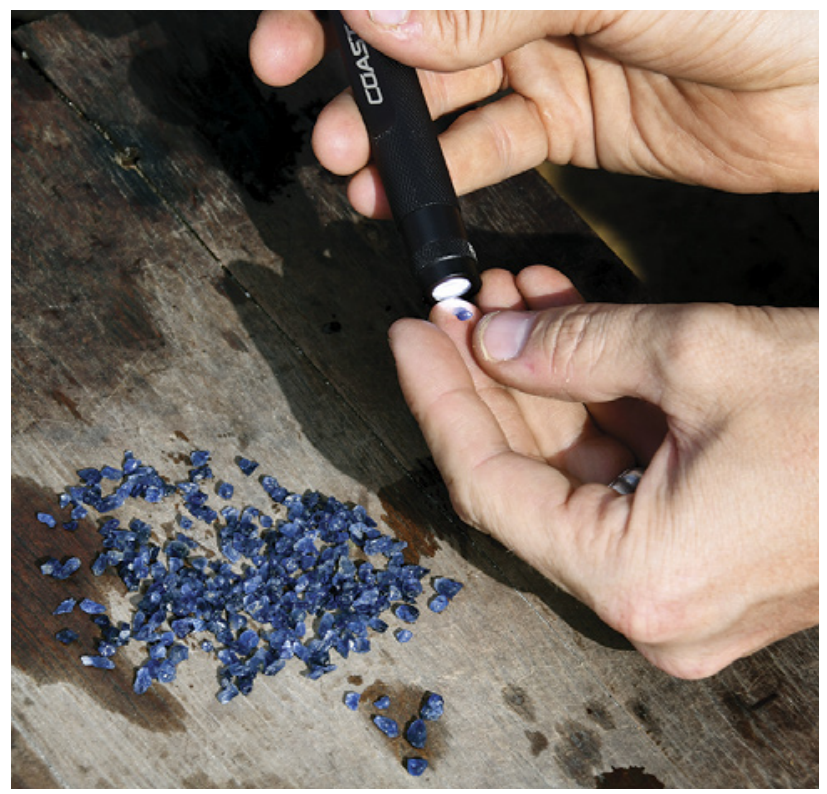




\begin{tabular}{|c|c|c|c|c|c|c|}
\hline Classification & $\begin{array}{l}\text { North } \\
(21)\end{array}$ & $\begin{array}{l}\text { Northeast } \\
\text { (32) }\end{array}$ & $\begin{array}{l}\text { East } \\
(22)\end{array}$ & $\begin{array}{l}\text { Northwest } \\
\quad(83)\end{array}$ & $\begin{array}{l}\text { West } \\
(40)\end{array}$ & $\begin{array}{l}\text { Far West } \\
\quad(50)\end{array}$ \\
\hline $\begin{array}{l}\text { A type: Mined by } \\
\text { GIA gemologist }\end{array}$ & - & - & - & - & - & - \\
\hline $\begin{array}{l}\text { B type: Mining observed } \\
\text { by GIA gemologist }\end{array}$ & - & 2 & - & - & 6 & - \\
\hline $\begin{array}{l}\text { C type: Purchased from } \\
\text { miner at the mine }\end{array}$ & - & - & 14 & - & 5 & - \\
\hline $\begin{array}{l}\text { D type: Purchased from } \\
\text { miner, not at the mine }\end{array}$ & - & 5 & 8 & 73 & 3 & - \\
\hline $\begin{array}{l}\text { E type: Purchased in the } \\
\text { local market }\end{array}$ & 21 & 25 & - & 10 & 26 & 50 \\
\hline
\end{tabular}

${ }^{a}$ From Vertriest et al. (2019). The numbers in parentheses represent the numbers of samples from each area.

with a set of parallel polished surface windows oriented either perpendicular or parallel to the crystal's c-axis (Thomas, 2009); and six faceted samples.

Standard gemological properties such as refractive index (RI), birefringence, and hydrostatic specific gravity (SG) were measured on all samples. A standard gemological UV lamp with long-wave (LW) and shortwave (SW) radiation at 365 and $254 \mathrm{~nm}$, respectively, was used for fluorescence observations. Microscopic examination was performed with GIA binocular microscopes at $10 \times$ to $70 \times$ magnification, using various lighting including darkfield, brightfield, diffused, and fiber-optic illumination. Photomicrographs were captured with Nikon SMZ 18 and 1500 systems at different magnifications and lighting.

Ultraviolet/visible/near-infrared (UV-Vis-NIR) spectra were collected on the 12 optical wafer samples with a Hitachi U-2900 spectrophotometer specially modified at GIA to include a rotatable polarizer to allow the separate collection of the ordinary (o-) and extraordinary (e-) rays at a wavelength resolution of $1.5 \mathrm{~nm}$. Fourier-transform infrared (FTIR) spectra were measured on all 248 samples using a Thermo Nicolet 6700 FTIR spectrometer operating with a $4 \times$ beam condenser accessory at a resolution of $4 \mathrm{~cm}^{-1}$. A Renishaw inVia Raman microscope fitted with a $514 \mathrm{~nm}$ argon-ion laser was used to identify mineral inclusions, when possible. This was also used for photoluminescence (PL) analysis with a $457 \mathrm{~nm}$ laser excitation at room temperature.

Trace element chemical analyses were performed on all samples using laser ablation-inductively coupled plasma-mass spectrometry (LA-ICP-MS) technology with a Thermo Fisher Scientific iCAP Q ICP-MS coupled with a Q-switched Nd:YAG laser ablation device operating at a wavelength of $213 \mathrm{~nm}$. The laser conditions used were $55 \mu \mathrm{m}$ diameter laser spots with a fluence of approximately $10 \mathrm{~J} / \mathrm{cm}^{2}$ and a repetition rate of $10 \mathrm{~Hz}$. The dwell time of each spot was $40 \mathrm{~s}$. The forward power was set at $1350 \mathrm{~W}$, and the typical nebulizer gas flow was approximately at $0.80 \mathrm{~L} / \mathrm{min}$. A special set of corundum reference standards was used for quantitative analysis of $\mathrm{Be}$, $\mathrm{Mg}, \mathrm{Ti}, \mathrm{V}, \mathrm{Cr}, \mathrm{Fe}$, and $\mathrm{Ga}$ (Stone-Sundberg et al., 2017), whereas NIST Standard Reference Materials 610 and 612 glasses were used for other elements. All elemental measurements were normalized on $\mathrm{Al}$ as the internal elemental standard.

\section{RESULTS AND DISCUSSION}

Gemological Properties and Appearance. Generally, sapphires produced from various areas in the Mogok Stone Tract have a range of blue color from light to strong saturation (figure 11). The standard gemological properties of the studied materials are typical of natural corundum: RI of 1.760-1.770, birefringence of 0.008-0.009, and hydrostatic SG of 3.81-4.04.

Viewed under a standard gemological UV lamp (365 and $254 \mathrm{~nm}$ ), the vast majority of Mogok blue sapphires in this study (81\%) showed no fluorescence under long-wave UV radiation, while $10 \%$ fluoresced red (without zoned orange fluorescence). The remainder displayed zoned orange fluorescence (with very weak or no red fluorescence) in near-colorless to light blue color zones. The fluorescence intensity under long-wave UV was generally weak to moderate. It should be noted that the red and orange fluorescence observed in these blue sapphires is caused by different defects (figure 12) and can appear together when observed with a gemological UV lamp. Orange fluo- 
North
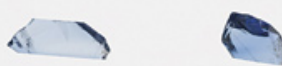

Northeast
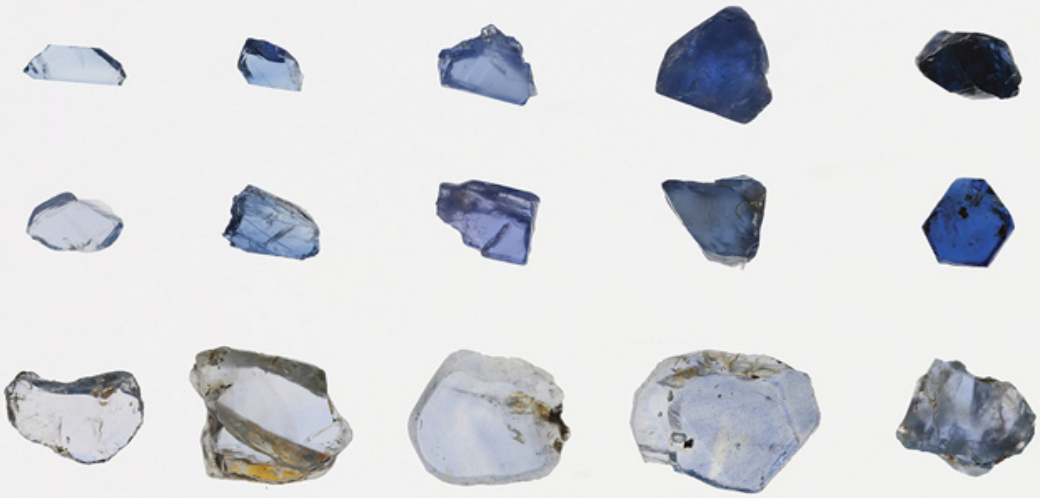

Northwest
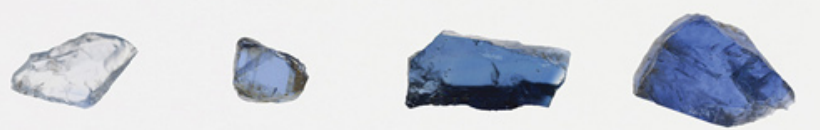

West
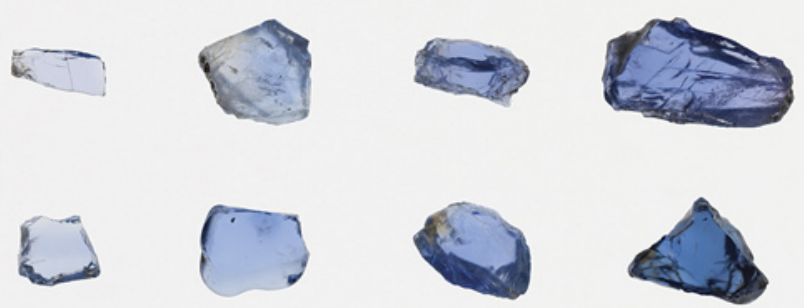

Far West
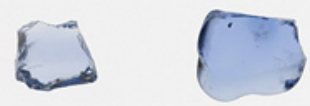
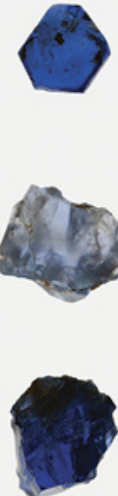

Figure 11. Colorcalibrated photos of blue sapphire samples from six different regions in the Mogok Stone Tract, Myanmar. Note that visual color intensity also depends on the sample thickness, ranging here from 0.68 to $3.55 \mathrm{~mm}$. Photos by Sasithorn Engniwat.
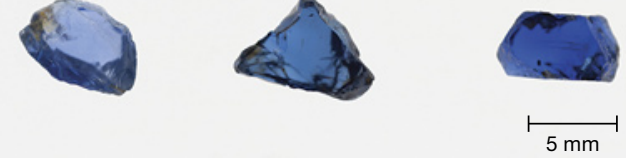

rescence is relatively common in metamorphic blue sapphire from other sources, such as Sri Lanka and Madagascar (Hughes et al., 2017). In figure 12, a stone with red fluorescence showed R-line emission at 693.0 and $694.4 \mathrm{~nm}$ that is caused by $\mathrm{Cr}^{3+}$. The or- ange fluorescent region displayed an additional emission band at around $640 \mathrm{~nm}$ that is related to trapped hole chromophores (Hughes et al., 2017). In natural corundum, the reaction under long-wave UV is generally stronger than that in short-wave UV. This was

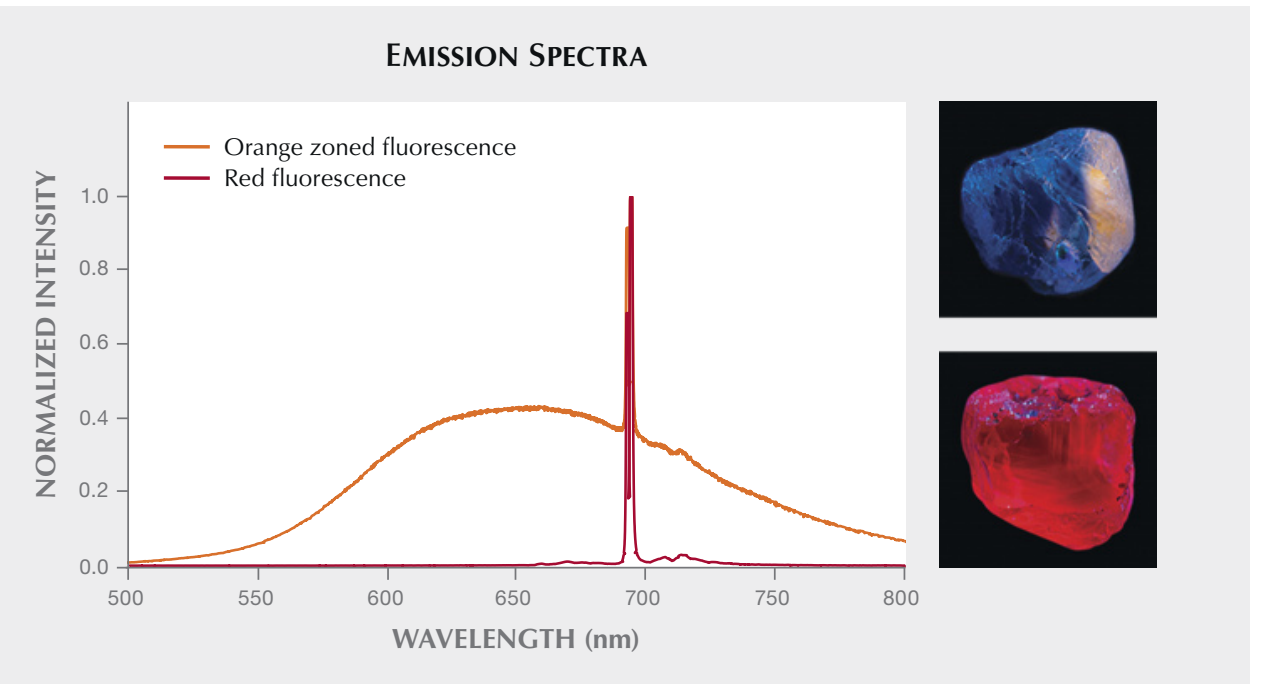

Figure 12. The emission spectrum of the orange zoned fluorescence of Mogok sapphire from the West area (orange line) and that of the red fluorescence of another sample from the Far West area (red line), using $457 \mathrm{~nm}$ laser excitation. Examples of orange zoned (top right) and red (bottom right) fluorescence of the samples under long-wave UV (365 nm). Photos by Nuttapol Kitdee. 


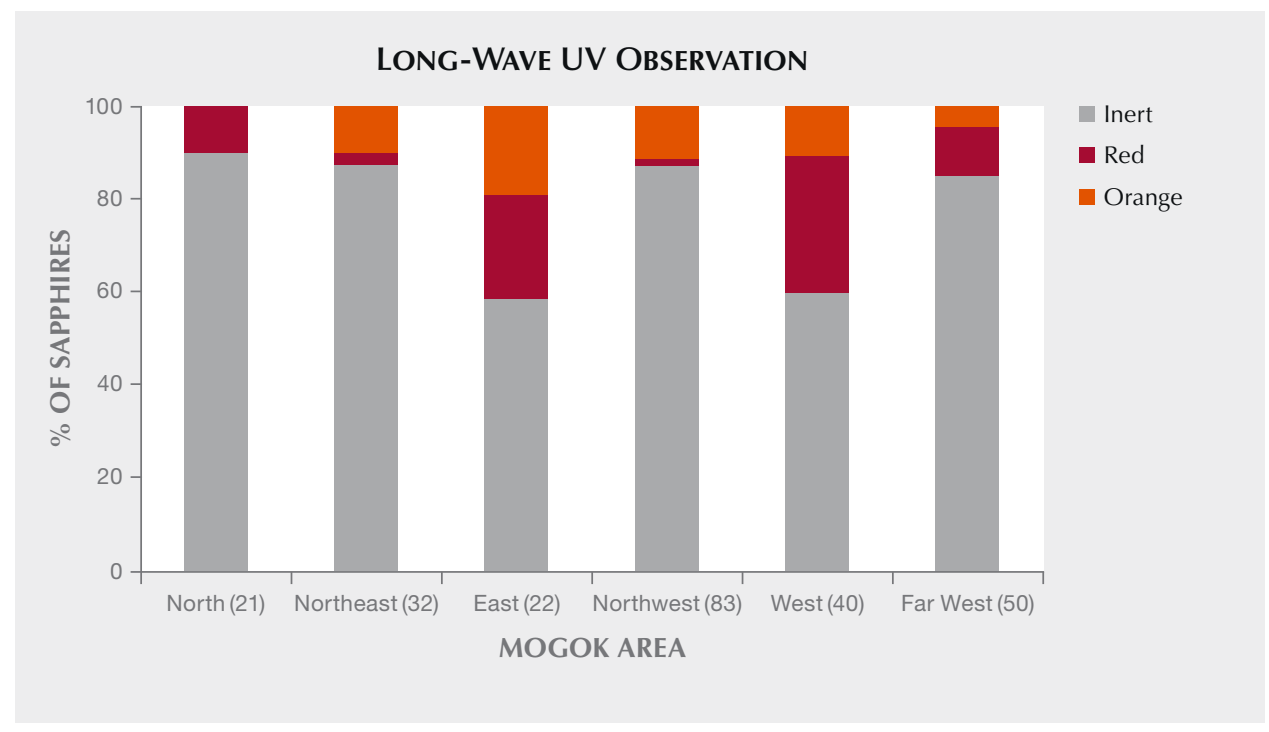

Figure 13. The longwave UV fluorescence reaction distribution of Mogok blue sapphires from different areas. A majority of the samples showed no fluorescence under long-wave UV. The numbers in parentheses represent the number of samples from each area.

confirmed in the studied Mogok sapphires, which were all inert under short-wave UV light.

The graph in figure 13 shows the observed fluorescence color under long-wave UV for Mogok sapphires in six different regions. Among the studied samples, blue sapphires from the West and East areas showed the highest percentage (40\%) displaying a fluorescent reaction. Among the samples with observable fluorescence, the North samples displayed only red fluo- rescence, whereas the samples from other areas exhibited both red and orange zoned fluorescence.

Microscopic Observation. The studied samples from the Mogok Stone Tract area presented similar internal features and exhibited many inclusions commonly seen in classic Mogok blue sapphires reported previously (Gübelin and Koivula, 2008; Hughes et al., 2017; Themelis, 2008), as summarized in table 2. Figure 14

Figure 14. The distribution of common internal features in blue sapphires from different mining regions along the Mogok Stone Tract. The numbers in parentheses represent the number of samples from each area.

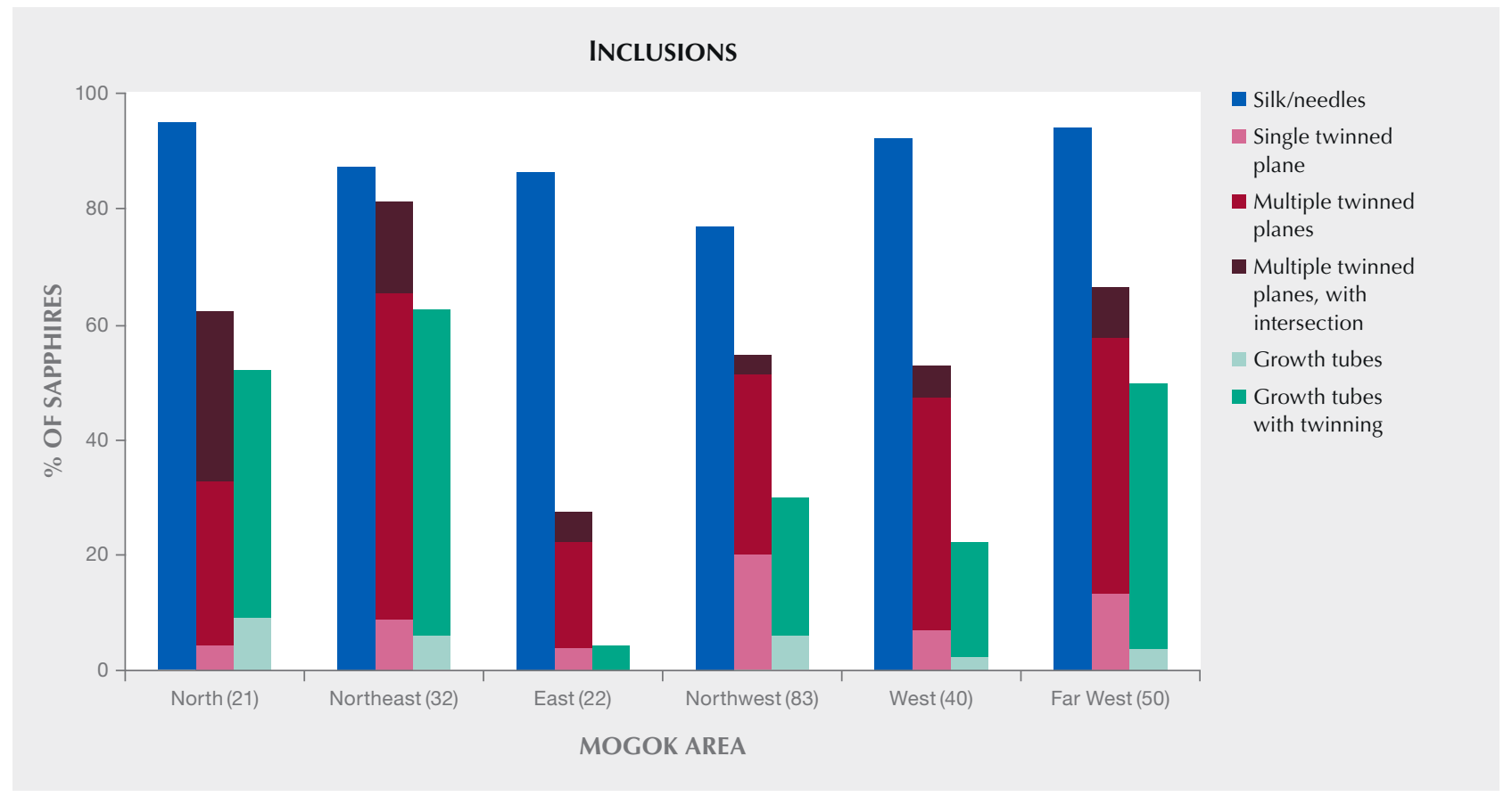


TABLE 2. General observation of blue sapphires from the Mogok Stone Tract area, Myanmar.

\begin{tabular}{|c|c|c|c|c|c|c|c|}
\hline Mining area & $\begin{array}{l}\text { North } \\
(21)\end{array}$ & $\begin{array}{l}\text { Northeast } \\
\quad(32)\end{array}$ & $\begin{array}{l}\text { East } \\
(22)\end{array}$ & $\begin{array}{l}\text { Northwest } \\
\quad(83)\end{array}$ & $\begin{array}{l}\text { West } \\
(40)\end{array}$ & $\begin{array}{c}\text { Far West } \\
\quad(50)\end{array}$ & Literature $^{\mathrm{a}}$ \\
\hline Weight (carats) & $0.21-4.26$ & $0.22-2.14$ & $1.04-27.36$ & $0.07-4.26$ & $0.11-6.15$ & $0.28-5.89$ & - \\
\hline Color & $\begin{array}{l}\text { Light to strong } \\
\text { blue }\end{array}$ & $\begin{array}{l}\text { Light to strong } \\
\text { blue, a few } \\
\text { with violetish } \\
\text { tint }\end{array}$ & $\begin{array}{l}\text { Light to } \\
\text { medium blue }\end{array}$ & $\begin{array}{l}\text { Light to strong } \\
\text { blue, a few } \\
\text { with violetish } \\
\text { tint }\end{array}$ & $\begin{array}{l}\text { Light to strong } \\
\text { blue, a few } \\
\text { with violetish } \\
\text { tint }\end{array}$ & $\begin{array}{l}\text { Light to strong } \\
\text { blue }\end{array}$ & $\begin{array}{l}\text { Light to strong } \\
\text { blue, some } \\
\text { with violetish } \\
\text { tint }\end{array}$ \\
\hline
\end{tabular}

\begin{tabular}{|c|c|c|c|c|c|c|c|}
\hline $\begin{array}{l}\text { Fluorescence } \\
\text { observation }\end{array}$ & $\begin{array}{l}\text { Generally inert } \\
\text { under long- } \\
\text { wave and } \\
\text { short-wave UV; } \\
\text { sometimes } \\
\text { weak red under } \\
\text { long-wave UV }\end{array}$ & $\begin{array}{l}\text { Generally iner } \\
\text { and/or orange }\end{array}$ & $\begin{array}{l}\text { under long-wav } \\
\text { oned under lon }\end{array}$ & $\begin{array}{l}\text { and short-wave } \\
\text { vave UV }\end{array}$ & V; sometimes we & k to medium red & $\begin{array}{l}\text { Generally inert, } \\
\text { weak red to } \\
\text { orange from } \\
\text { Cr-bearing } \\
\text { stones may be } \\
\text { observed under } \\
\text { long-wave UV }\end{array}$ \\
\hline $\begin{array}{l}\text { Internal } \\
\text { features }\end{array}$ & $\begin{array}{l}\text { Needles/silk, } \\
\text { polysynthetic } \\
\text { twinning, } \\
\text { growth tubes, } \\
\text { fingerprints, } \\
\text { and negative } \\
\text { crystals. } \\
\text { Generally } \\
\text { uniform blue } \\
\text { color, lacking a } \\
\text { sharp blue } \\
\text { boundary. }\end{array}$ & $\begin{array}{l}\text { Needles/silk, } \\
\text { polysynthetic } \\
\text { twinning, } \\
\text { growth tubes, } \\
\text { fingerprints, } \\
\text { and negative } \\
\text { crystals. } \\
\text { Generally } \\
\text { uniform blue } \\
\text { color. }\end{array}$ & $\begin{array}{l}\text { Needles/silk, } \\
\text { polysynthetic } \\
\text { twinning, } \\
\text { fingerprints, } \\
\text { and negative } \\
\text { crystals. } \\
\text { Generally } \\
\text { uniform blue } \\
\text { color. }\end{array}$ & $\begin{array}{l}\text { Needles/silk, } \\
\text { polysynthetic } \\
\text { twinning, } \\
\text { growth tubes, } \\
\text { fingerprints, } \\
\text { and negative } \\
\text { crystals. } \\
\text { Generally } \\
\text { uniform blue } \\
\text { color. }\end{array}$ & $\begin{array}{l}\text { Needles/silk, } \\
\text { polysynthetic } \\
\text { twinning; } \\
\text { growth tubes, } \\
\text { fingerprints, } \\
\text { and negative } \\
\text { crystals. } \\
\text { Generally } \\
\text { uniform blue } \\
\text { color, lacking a } \\
\text { sharp blue } \\
\text { zone. }\end{array}$ & $\begin{array}{l}\text { Needles/silk, } \\
\text { polysynthetic } \\
\text { twinning, } \\
\text { growth tubes, } \\
\text { fingerprints, } \\
\text { and negative } \\
\text { crystals. } \\
\text { Generally } \\
\text { uniform blue } \\
\text { color, lacking a } \\
\text { sharp blue } \\
\text { zone. }\end{array}$ & $\begin{array}{l}\text { Polysynthetic } \\
\text { twinning, } \\
\text { growth tubes, } \\
\text { rutile silk, } \\
\text { secondary fluid } \\
\text { inclusions, and } \\
\text { negative } \\
\text { crystals. Even } \\
\text { blue color, } \\
\text { rarely with } \\
\text { color banding, } \\
\text { and lacking } \\
\text { sharp growth } \\
\text { zoning. }\end{array}$ \\
\hline
\end{tabular}

\begin{tabular}{|c|c|c|c|c|c|c|c|}
\hline $\begin{array}{l}\text { Solid } \\
\text { crystalline } \\
\text { inclusions }\end{array}$ & $\begin{array}{l}\text { Apatite, calcite, } \\
\text { corundum, } \\
\text { feldspar, mica, } \\
\text { monazite, } \\
\text { nepheline, } \\
\text { zircon, and } \\
\text { green sheets }\end{array}$ & $\begin{array}{l}\text { Feldspar, mica, } \\
\text { rutile, spinel, } \\
\text { green sheets, } \\
\text { and tiny } \\
\text { opaque black } \\
\text { crystals }\end{array}$ & $\begin{array}{l}\text { Apatite, } \\
\text { feldspar, mica, } \\
\text { spinel, zircon, } \\
\text { and tiny } \\
\text { opaque black } \\
\text { crystals }\end{array}$ & $\begin{array}{l}\text { Apatite, } \\
\text { feldspar, mica, } \\
\text { rutile, spinel, } \\
\text { zircon, green } \\
\text { sheets, and tiny } \\
\text { opaque black } \\
\text { crystals }\end{array}$ & $\begin{array}{l}\text { Apatite, calcite, } \\
\text { feldspar, mica, } \\
\text { nepheline, } \\
\text { rutile, } \\
\text { scapolite, } \\
\text { zircon, and } \\
\text { tiny opaque } \\
\text { black crystals }\end{array}$ & $\begin{array}{l}\text { Apatite, calcite, } \\
\text { feldspar, mica, } \\
\text { rutile, } \\
\text { scapolite, } \\
\text { spinel, zircon, } \\
\text { and tiny } \\
\text { opaque black } \\
\text { crystals }\end{array}$ & $\begin{array}{l}\text { Apatite, } \\
\text { brookite, } \\
\text { dolomite, } \\
\text { fergusonite, } \\
\text { feldspar, } \\
\text { gibbsite, mica, } \\
\text { monazite, } \\
\text { nepheline, } \\
\text { pargasite, } \\
\text { rutile, spinel, } \\
\text { uraninite, } \\
\text { zircon, and } \\
\text { pyrrhotite }\end{array}$ \\
\hline
\end{tabular}

${ }^{a}$ Gübelin and Koivula (2008), Themelis (2008), Kan-Nyunt et al. (2013), Saengbuangamlam et al. (2016), and Hughes et al. (2017).

illustrates the distribution of internal features commonly observed in the studied Mogok sapphires separated by mining locations. The most common inclusion types are rutile needles/silk; they were observed in more than $80 \%$ of the samples. Silk can occur in various patterns, often overlapping with those of other metamorphic deposits, such as Sri Lanka and Madagascar (Palke et al., 2019). They can consist of densely packed short needles, a mix of short and long needles in zones or discrete bands, and sometimes arrowhead patterns (figure 15, A-C). Mogok sapphires can also have irregular/flaky iridescent platelets, presumably ilmenite (Kan-Nyunt et al., 2013), bands/zones of coarse particles with short needles, and rounded/elongated reflective platelets (figure 15, D-G). When oblique fiber-optic light is reflected from the surface of the silk, the needles/platelets exhibit iridescent colors (e.g., figure 15, A and D, and figure 16, left). Using other lighting 

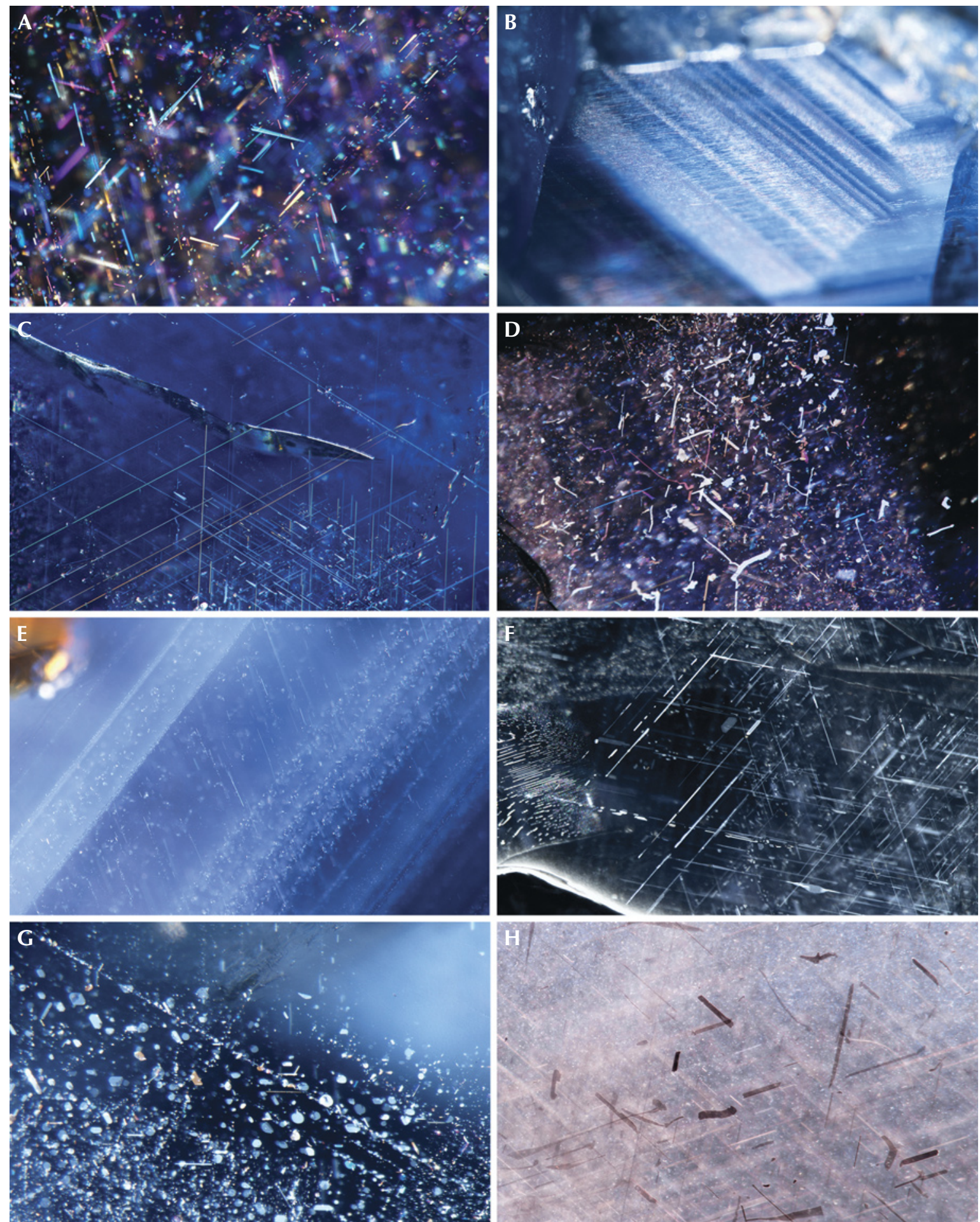

Figure 15. Patterns of silk and needles in Mogok sapphires. A: Iridescent rutile silk with arrowhead pattern observed with a fiber-optic light from the appropriate angle. B: Densely packed rutile short needles in discrete bands. C: A mix of short and long rutile silk. D: Irregularly shaped reflective platelets and needles. E: Bands of coarse particles mixed with short needles. F: Intersection of elongated reflective thin films. G: Reflective rounded platelets mixed with short needles. $H$ : A mix of whitish and brownish silk. Photomicrographs by C. Khowpong (A, E, F), U. Atikarnsakul (B, D, G), S. Wongchacree (C), and V.L. Raynaud-Flattot (H). Fields of view: $1.40 \mathrm{~mm}(A), 3.10 \mathrm{~mm}(B), 1.40 \mathrm{~mm}(C), 2.40 \mathrm{~mm}(D), 1.80 \mathrm{~mm}(E), 3.65 \mathrm{~mm}(F), 0.80$ $\mathrm{mm}(G)$, and $1.05 \mathrm{~mm}(H)$. Shown in fiber-optic $(A-G)$ and darkfield illumination $(H)$. 

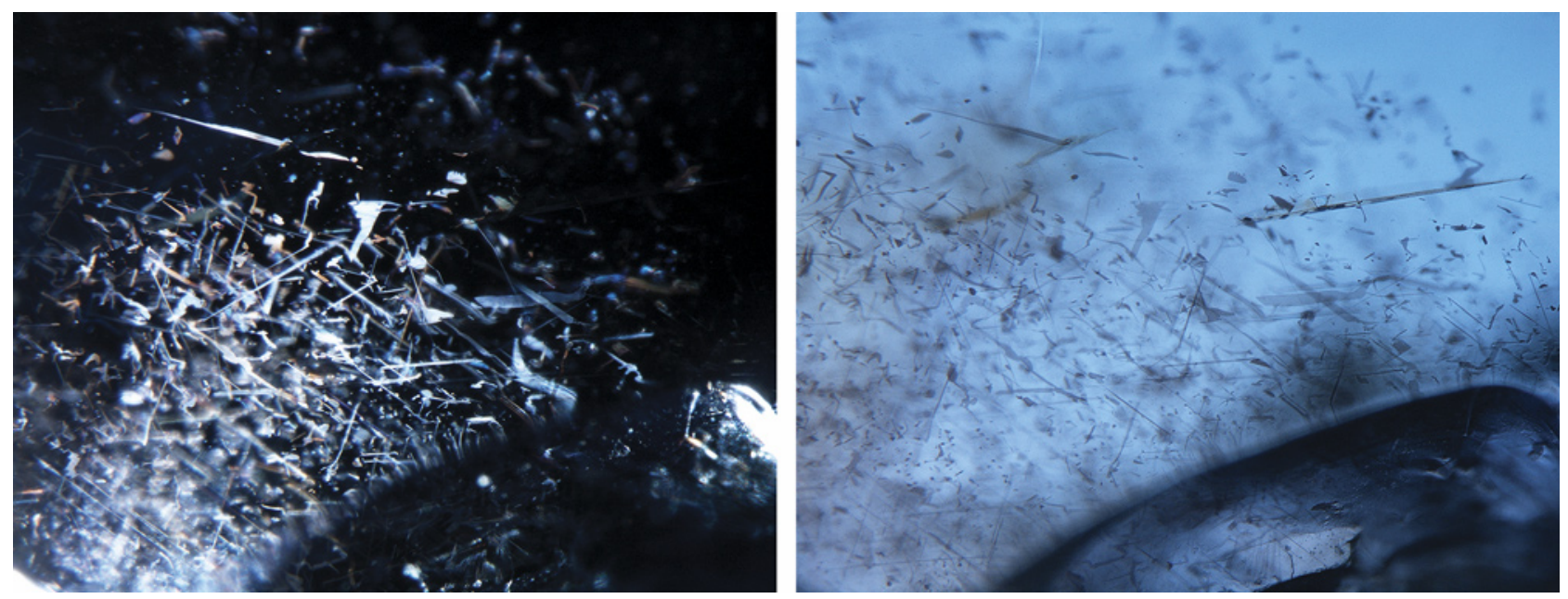

Figure 16. This Mogok sapphire shows densely packed irregular platelets and needles. This type of silk appears reflective and iridescent when a fiber-optic light is shone through at an appropriate angle (left) and brownish when viewed with other lighting conditions (right, diffused illumination). Photomicrographs by Ungkhana Atikarnsakul; field of view $1.50 \mathrm{~mm}$.

conditions, the rutile silk commonly appeared whitish (e.g., figure 15, B and G), while irregular/flaky platelets generally look brownish (e.g., figures $15 \mathrm{H}$ and 16, right). Irregular brownish platelets (presumably ilmenite) are noticeably seen in the sapphires containing high iron (Fe) content (>800 ppma Fe).

Other frequently observed features are polysynthetic twin planes on the rhombohedron and growth tubes along twin planes. Twinning is usually present as multiple planes, sometimes intersecting in the samples (figures 14 and 17, left). Rose channels (growth tubes at twin intersections) are occasionally filled by boehmite/diaspore (figure 17, right) (Notari et al., 2018).

In Mogok sapphires, healed fissures or fingerprints can be present in various ways, such as folded, coarse, zig-zag fluid, and fingerprints where individual negative crystals are easily recognized (figure 18, A-D). In addition, the blue sapphires from Mogok sometimes contain large negative crystals surrounded by iridescent fluid thin films ("rosettes") (figure 19) (Raynaud and Vertriest, 2017). Mogok sapphires typically have

Figure 17. Intersecting twinned sectors viewed under crossed polarizing filters are sometimes observed in Mogok sapphires (left). Intersecting growth tubes filled by boehmite can also be present along twinned planes (right), usually suggesting a Burmese origin. Photomicrographs by Ungkhana Atikarnsakul; field of view $7.20 \mathrm{~mm}$ (left) and $1.20 \mathrm{~mm}$ (right).
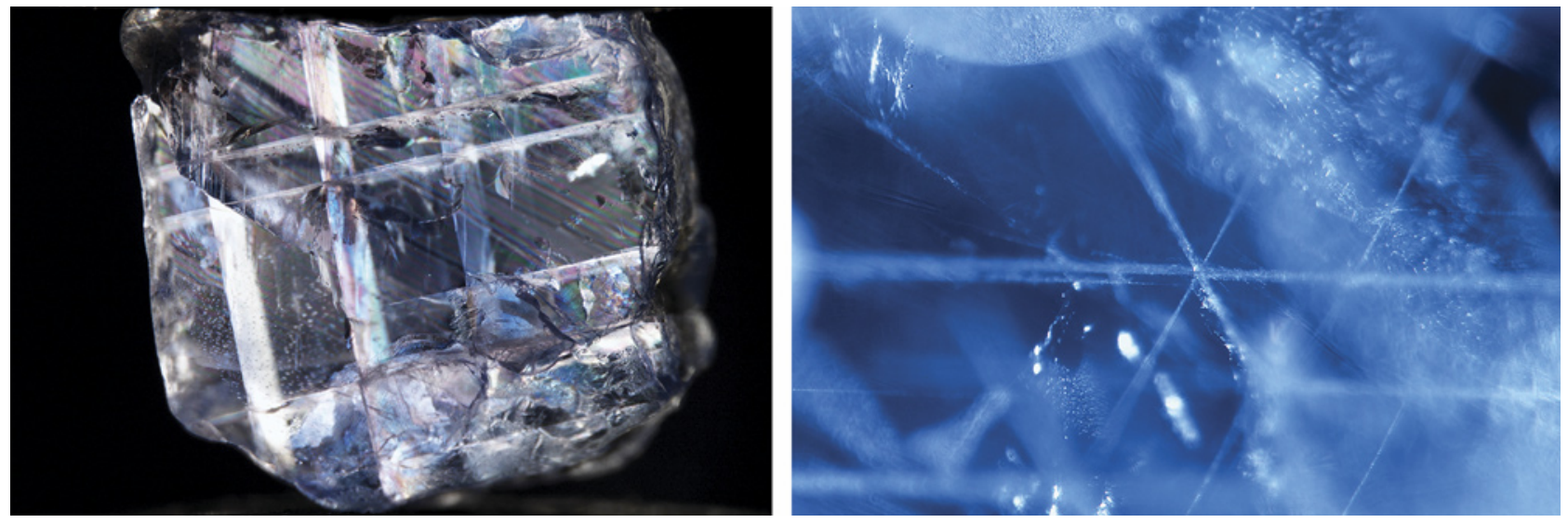

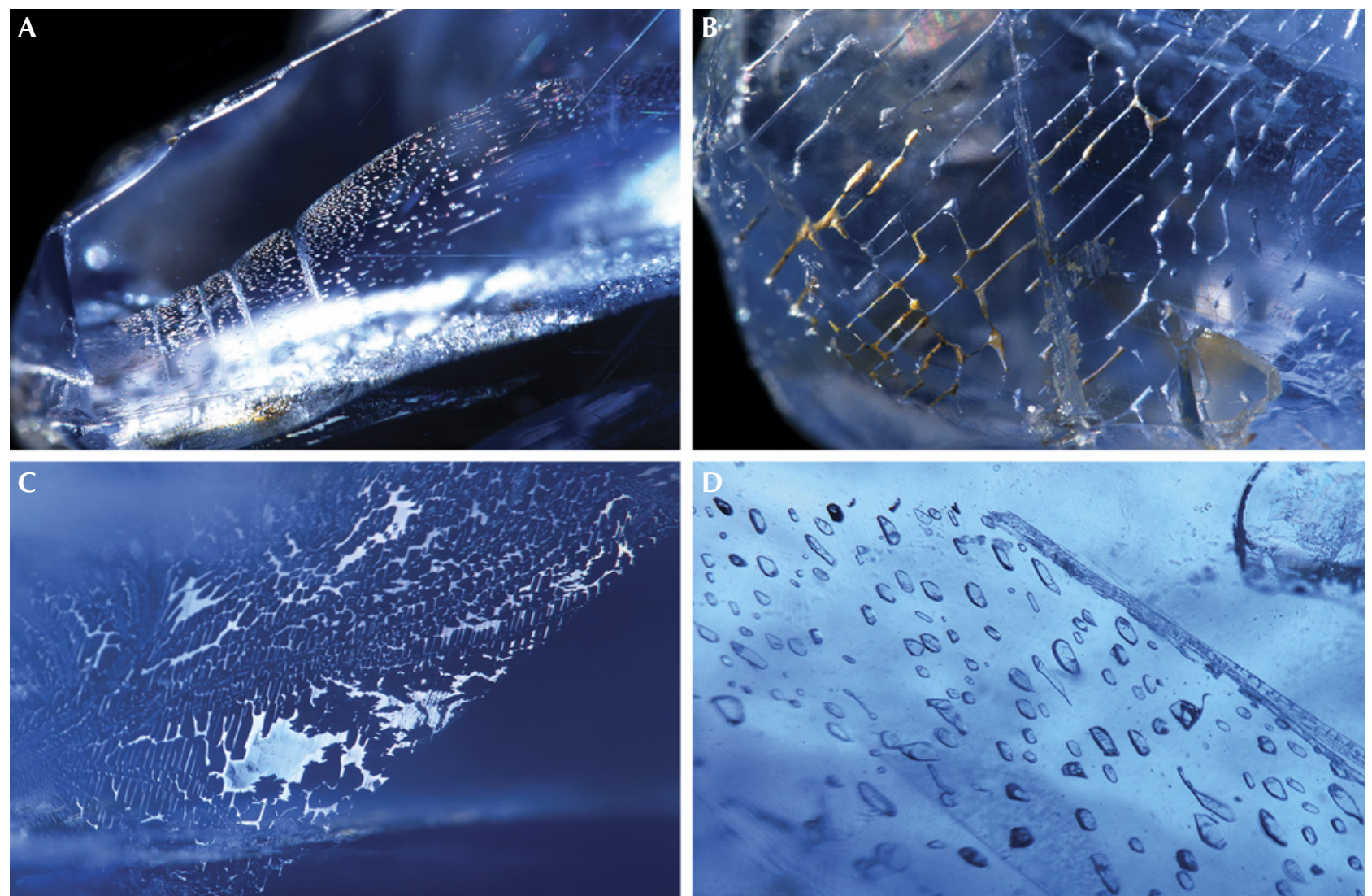

Figure 18. Healed fractures in samples from Mogok. A: Folded fingerprint. B: Coarse and slender healed fractures with iron stains. C: Fluid fingerprint with a zig-zag pattern. D: Fingerprint-like plane of tabular negative crystals. Photomicrographs by Suwasan Wongchacree (A and B) and Charuwan Khowpong (C and D). Field of view: 2.40 $\mathrm{mm}(A), 2.88 \mathrm{~mm}(B), 1.80 \mathrm{~mm}(C)$, and $1.10 \mathrm{~mm}(D)$. Shown in fiber-optic $(A-C)$ and darkfield illumination (D).

an even blue color. However, in a small percentage (approximately 10\%) of the studied samples, diffused blue color zoning lacking sharp boundaries can be ob- served (figure 20). Color zoning with sharp, well-defined boundaries can sometimes be seen, though rare (figure 21). Only three out of 248 samples in this
Figure 19. This Mogok sapphire contains a negative crystal surrounded by iridescent thin films. Photomicrograph by Suwasan Wongchacree, fiber-optic illumination; field of view $1.44 \mathrm{~mm}$.

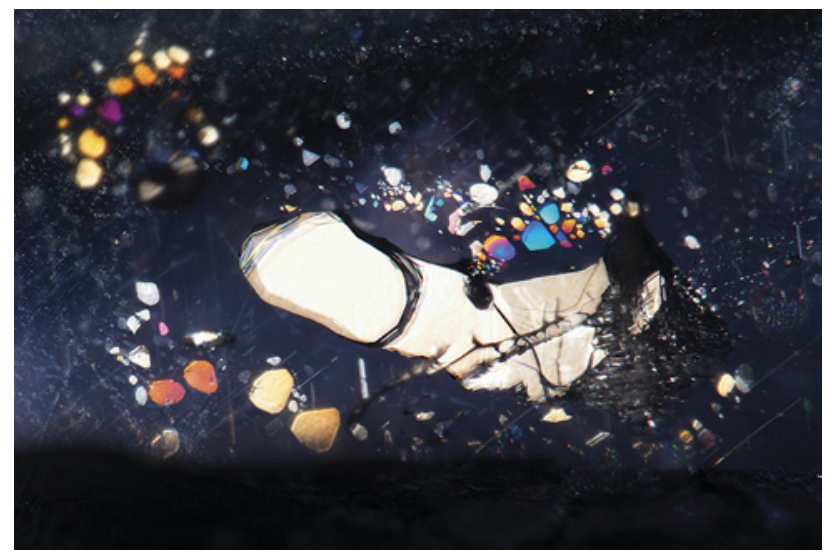

Figure 20. Diffuse blue zoning can be seen in Mogok sapphires. Photomicrograph by Suwasan Wongchacree, diffused illumination; field of view $14.4 \mathrm{~mm}$.

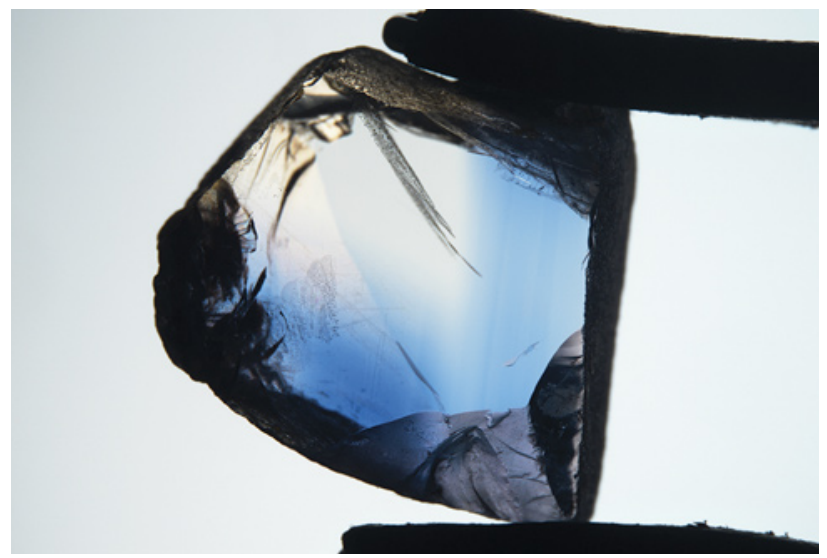




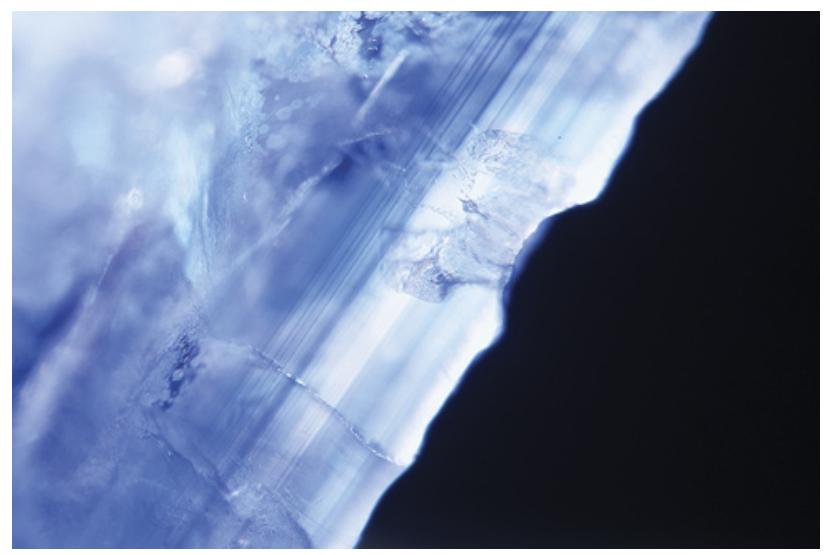

Figure 21. The straight and sharp blue zoning in this Mogok sapphire from the Northwest area is very rare. Photomicrograph by Charuwan Khowpong, fiberoptic illumination; field of view $1.40 \mathrm{~mm}$.
Multiple mineral crystals were found in the Mogok sapphires (table 2), but they are not diagnostic evidence for Burmese origin. In this study, apatite, calcite, corundum, feldspar, mica, monazite, nepheline, rutile, scapolite, spinel, and zircon, as well as green sheets and tiny opaque black crystals were observed and identified (figure 22, opposite page). Most of these mineral crystals, except for scapolite, are reported in previous studies for blue sapphires (Gübelin and Koivula, 2008; Themelis, 2008; Kan-Nyunt et al., 2013; Saengbuangamlam et al., 2016; Hughes et al., 2017). Scapolite inclusions have been identified in Burmese rubies (Kammerling et al., 1994), and to our knowledge this is the first reporting of scapolite in Burmese sapphires. The occurrence of specific mineral inclusions in Mogok sapphires identified by Raman spectroscopy is summarized in figure 23 , with feldspar and mica being the most common.

Infrared (IR) Absorption Spectroscopy. The infrared absorption region of interest in corundum is approxareas-display straight and sharp blue bands.

Figure 23. This graph shows the percentage of the samples that contained at least one conclusively identified crystal. The most common crystals in Mogok sapphire are feldspar and mica. The numbers in parentheses represent the number of samples from each area.

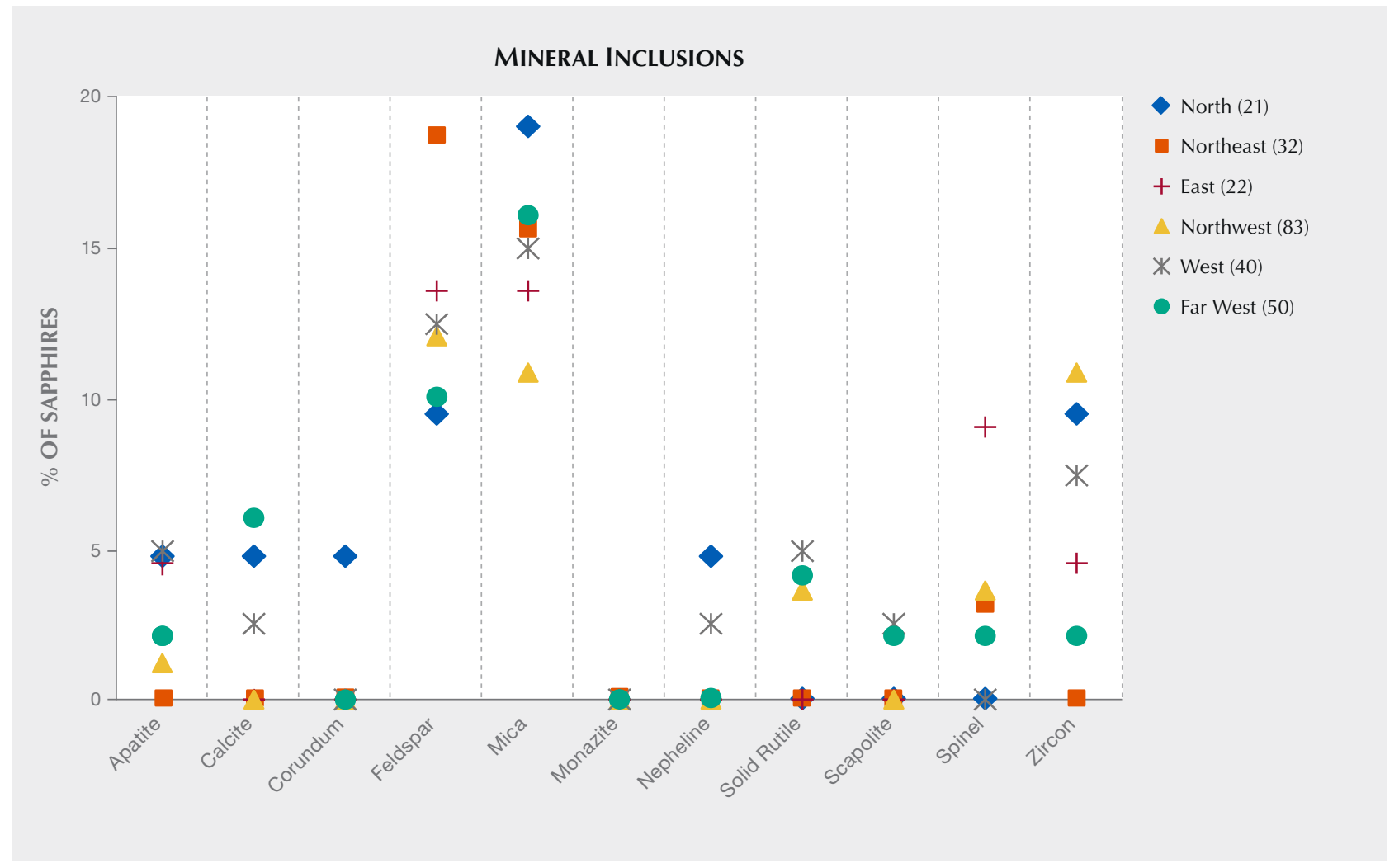



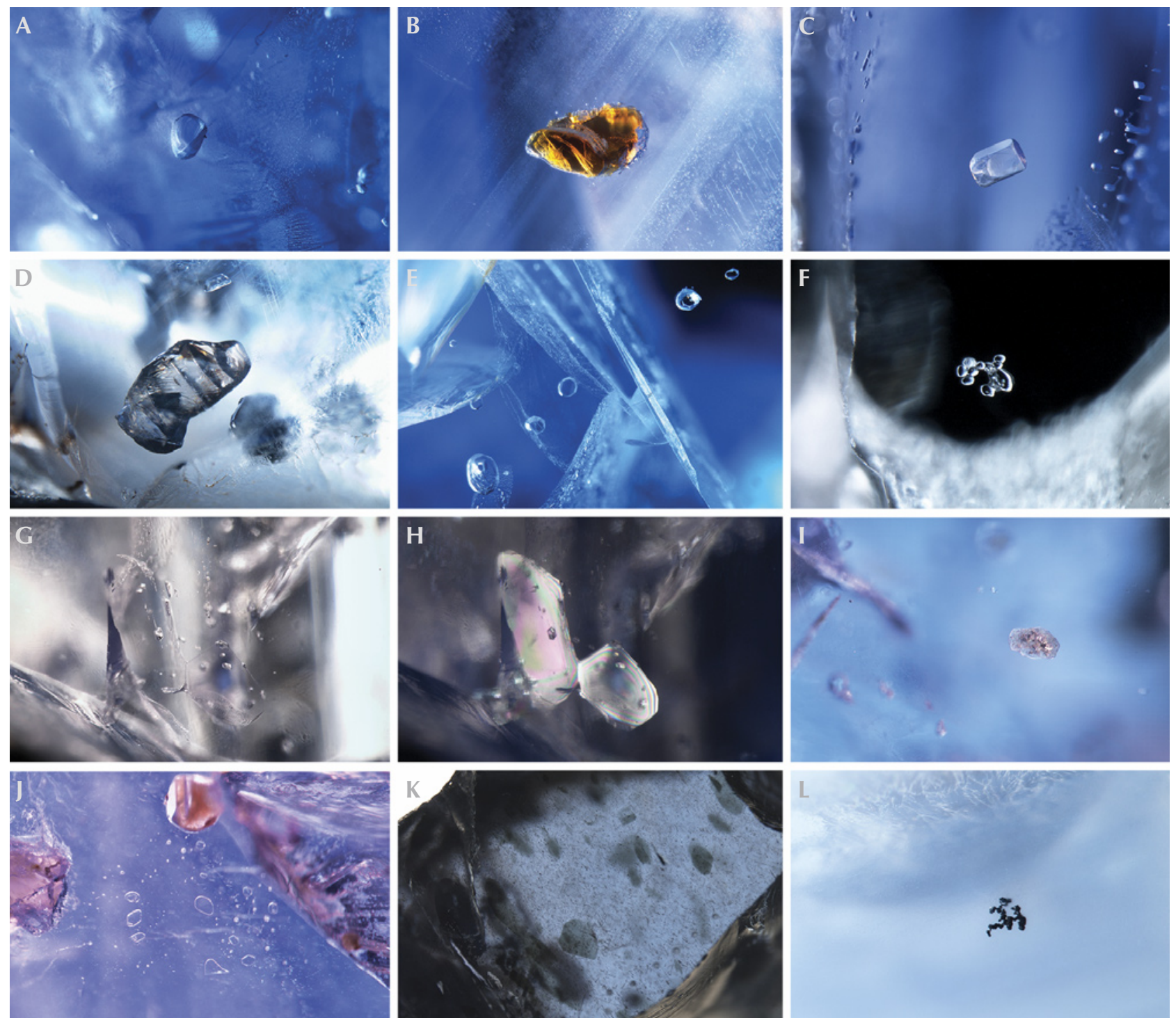

Figure 22. Mineral inclusions in Mogok sapphires. A: Rounded transparent colorless feldspar crystal. B: Transparent brownish mica crystal. C: Prismatic transparent apatite crystal. D: Rounded, unevenly shaped transparent rutile crystal. E: A row of prismatic transparent scapolite crystals. F: A group of rounded transparent zircon crystals. Zircon is more often seen as a single crystal. G: Low-relief transparent corundum crystals associated with small negative crystals. H: Birefringent crystals of corundum in $G$ viewed with crossed polarizing filters. I: Rounded transparent yellowish monazite crystal. J: Rounded transparent flat nepheline crystals. K: Unevenly shaped flat green transparent crystals (presumably mica). L: A group of small, blocky black opaque crystals. Photomicrographs by Charuwan Khowpong $(A, B, G, H, K)$ and Ungkhana Atikarnsakul (C, D, E, F, I, I, L). Field of view: $1.80 \mathrm{~mm}(A), 2.40 \mathrm{~mm}(B), 1.44 \mathrm{~mm}(C), 2.70 \mathrm{~mm}(D), 2.70 \mathrm{~mm}(E), 1.00 \mathrm{~mm}(F), 1.80 \mathrm{~mm}$ (G), $1.80 \mathrm{~mm}(H), 1.20 \mathrm{~mm}(I), 1.20 \mathrm{~mm}(J), 3.65 \mathrm{~mm}(K)$, and $1.05 \mathrm{~mm}(L)$. Shown in fiber-optic $(A-C, E-F, L)$, darkfield $(D, G, J)$, brightfield illumination $(H-I)$, and diffused illumination $(K)$.

imately $1800-4000 \mathrm{~cm}^{-1}$, which is related to hydroxyl $(\mathrm{OH})$ absorption. IR spectroscopic information can help detect heat treatment in corundum, such as the presence of a series of sharp peaks at approximately
$3309,3232,3187$, and $3368 \mathrm{~cm}^{-1}$ (Smith, 1995), and also reveal the presence of several OH-related mineral inclusions. The vast majority of Mogok samples in the study $(>90 \%)$ showed at least one diagnostic 


\section{FTIR ABSORPTION SPECTRA}
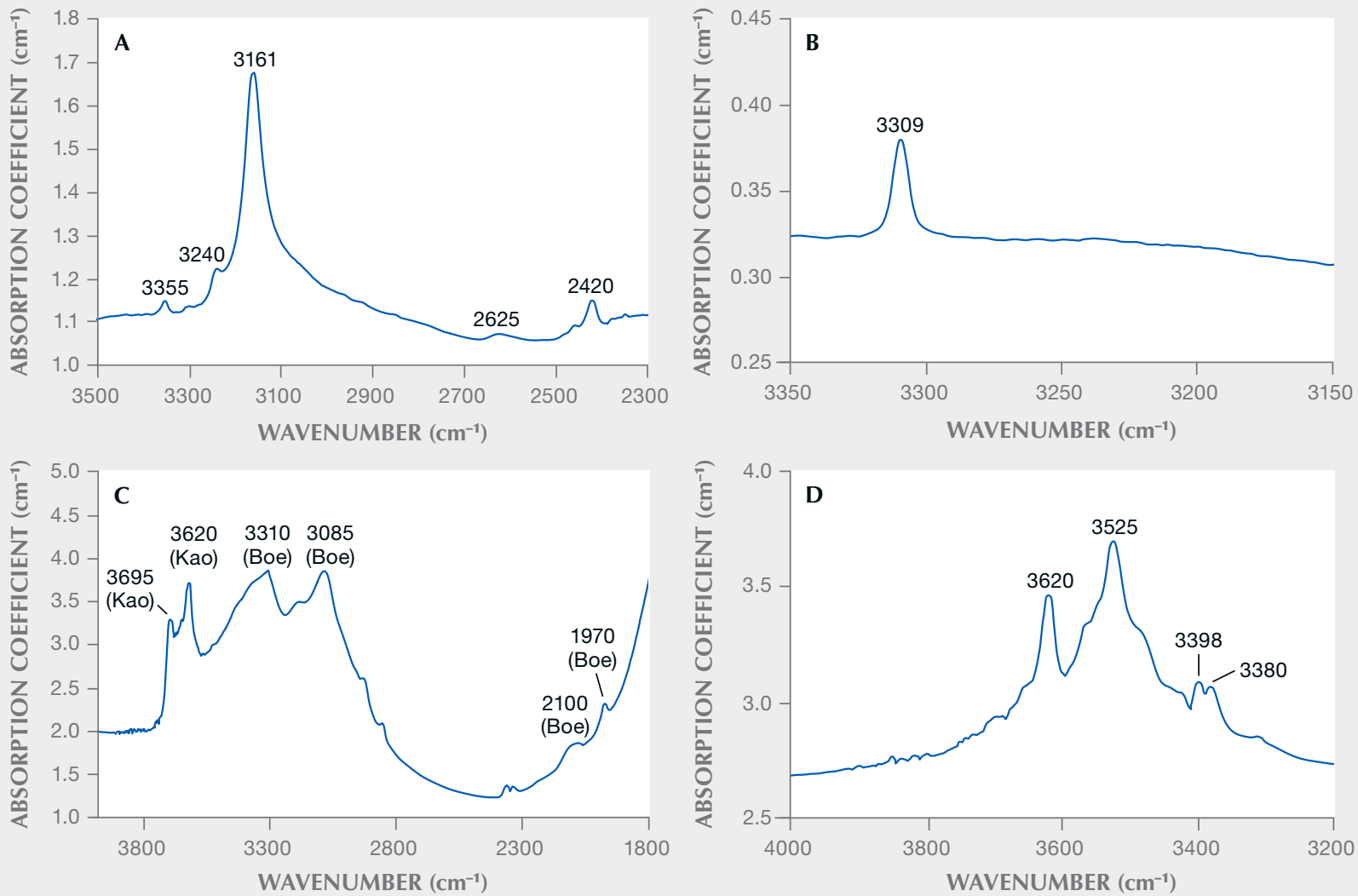

Figure 24. Unpolarized FTIR absorption spectra of the studied Mogok blue sapphires showed several features in the mid-infrared region between 1800 and $4000 \mathrm{~cm}^{-1}$. A: A prominent band at $3161 \mathrm{~cm}^{-1}$, sometimes associated with related bands at 2420, 3240, and $3355 \mathrm{~cm}^{-1}$. B: A single peak at $3309 \mathrm{~cm}^{-1}$ (without related bands at 3232 and $3186 \mathrm{~cm}^{-1}$ ). C: A combination of kaolinite (Kao) and boehmite (Boe) features with distinct bands at 3500-3800 and 1800-3600 $\mathrm{cm}^{-1}$, respectively. D: Gibbsite with distinct features at 3300-3800 $\mathrm{cm}^{-1}$.

IR feature (figure 24): the single $3309 \mathrm{~cm}^{-1}$ peak (Beran and Rossman, 2006), the $3161 \mathrm{~cm}^{-1}$ peak sometimes associated with side bands at 2420, 3240, and $3355 \mathrm{~cm}^{-1}$ (Smith and Van der Bogert, 2006), and some OH-related mineral absorption features, such as diaspore, boehmite, kaolinite, and gibbsite (Smith, 1995; Beran and Rossman, 2006).

Figure 25 shows the distribution of FTIR features observed in samples from each region in the Mogok Stone Tract. Mineral features were observed in more than $80 \%$ of the samples from all regions. The single $3309 \mathrm{~cm}^{-1}$ peak is present in the samples from each area, whereas the $3161 \mathrm{~cm}^{-1}$ feature can be found in a small percentage $(<5 \%)$ of Northeast, East, Northwest, and Far West samples. We noted that the studied sapphires exhibiting the $3161 \mathrm{~cm}^{-1}$ IR feature frequently show orange zoned fluores- cence, which is related to trapped-hole defects (as mentioned in the Gemological Properties and Appearance section).

UV-Vis-NIR Absorption Spectroscopy. All spectralquality samples from the Mogok Stone Tract exhibited similar UV-Vis-NIR spectra, as shown in figure 26. The spectra generally consist of $\mathrm{Fe}^{3+}$-related absorption features with a shoulder at $330 \mathrm{~nm}$ and peaks at 377,388 , and $450 \mathrm{~nm}$, and also a $\mathrm{Fe}^{2+}-\mathrm{Ti}^{4+}$ intervalence charge-transfer feature with a broad band centered at $580 \mathrm{~nm}$ in the o-ray or at $700 \mathrm{~nm}$ in the e-ray spectrum (Dubinsky et al., 2020). Sometimes, the shoulder at $330 \mathrm{~nm}$ of an $\mathrm{Fe}^{3+}-\mathrm{Fe}^{3+}$ pair is not observed due to the samples' relatively high Fe concentration (Dubinsky et al., 2020). The spectra shown in figure 26A are typical of the metamorphic-type sapphire spectrum 


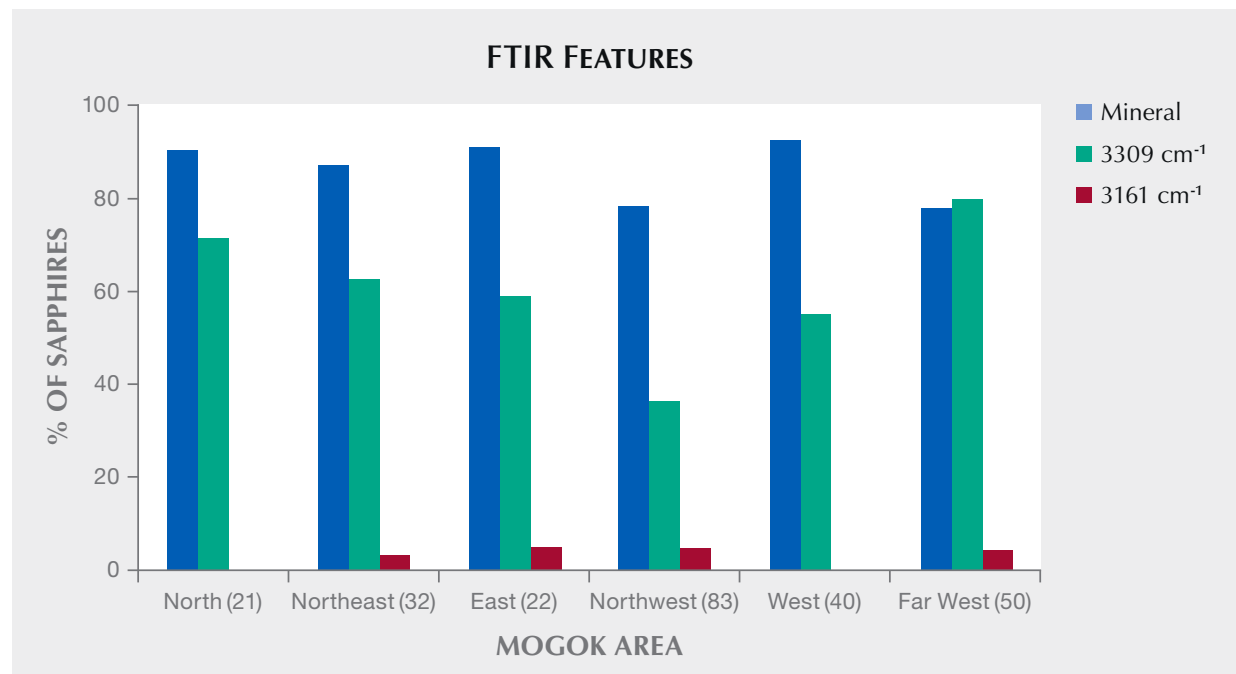

Figure 25. The distribution of FTIR features seen in Mogok sapphires from different regions in the present study. Mineral features (e.g., gibbsite, kaolinite, boehmite, and diaspore) and the single peak at $3309 \mathrm{~cm}^{-1}$ are frequently observed, whereas the $3161 \mathrm{~cm}^{-1}$ peak seems to be uncommon. The numbers in parentheses represent the number of samples studied from each area.

(Smith, 2010; Palke et al., 2019). Some high-Fe Mogok sapphires show a weak broad absorption band in the near-infrared region around $880 \mathrm{~nm}$ in addition to $\mathrm{Fe}^{3+}$ and $\mathrm{Fe}^{2+}-\mathrm{Ti}^{4+}$ absorption features in the UV-Vis region (figure 26B). This feature is common in basalt-related sapphires but not typically associated with untreated classic metamorphic sapphires (Kan-Nyunt et al., 2013; Soonthorntantikul et al., 2017). This $880 \mathrm{~nm}$ absorption band is possibly related to Fe clusters (Hughes et al., 2017).

Spectroscopic characteristics of Mogok blue sapphires in this study were also summarized in table 3.
Trace Element Chemistry. LA-ICP-MS data analyzed in inclusion-free and/or less particle-included areas for the studied Mogok blue sapphires are reported in table 4. Significant levels of $\mathrm{Mg}, \mathrm{Fe}, \mathrm{Ti}$, and Ga with a few ppma of $\mathrm{V}$ and $\mathrm{Cr}$ were measured in those samples (see also Peucat et al., 2007; KanNyunt et al., 2013; Atikarnsakul et al., 2018). The overall data exhibited a wide range of Fe concentrations from 100 ppma to 2300 ppma. The $\mathrm{Mg}$ and $\mathrm{Ti}$ concentrations can vary a lot depending on the presence of microinclusions (nanometers to nearly millimeters in size), with big differences between the

Figure 26. Two representative polarized UV-Vis-NIR absorption spectra of Mogok sapphires revealed Fe-related absorption at 330, 377, 388, and $450 \mathrm{~nm}$ in both the o- and e-rays and $\mathrm{Fe}^{2+}$-Ti ${ }^{4+}$ intervalence charge transfer at $580 \mathrm{~nm}$ in the o-ray, which is responsible for blue color in corundum. A: The absence of the $880 \mathrm{~nm}$ band is typical of metamorphic-type sapphire. The sample is from the North area, optical path length $1.059 \mathrm{~mm}, 1457 \pm 36$ ppma Fe and $42 \pm 5$ ppma Ti. B: The o-ray exhibited an additional weak broad band around $880 \mathrm{~nm}$, possibly due to Fe clusters. The sample is from the Northwest area, optical path length $1.008 \mathrm{~mm}, 1496 \pm 100 \mathrm{ppma}$ Fe and $19 \pm 2$ ppma Ti.

\section{UV-VIS-NIR ABSORPTION SPECTRA}
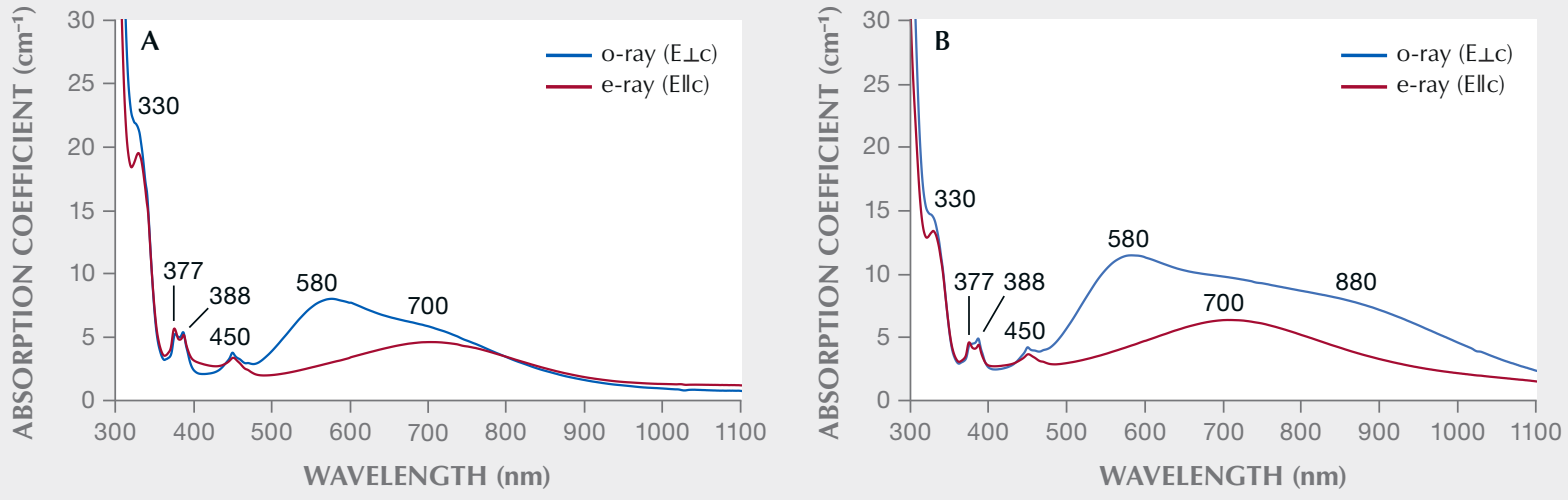
TABLE 3. Spectroscopic characteristics of blue sapphires from the Mogok Stone Tract area, Myanmar.

\begin{tabular}{|c|c|c|c|c|c|c|}
\hline Mining area & $\begin{array}{l}\text { North } \\
(21)\end{array}$ & $\begin{array}{l}\text { Northeast } \\
(32)\end{array}$ & $\begin{array}{l}\text { East } \\
(22)\end{array}$ & $\begin{array}{l}\text { Northwest } \\
\quad(83)\end{array}$ & $\begin{array}{l}\text { West } \\
(40)\end{array}$ & $\begin{array}{l}\text { Far West } \\
\quad(50)\end{array}$ \\
\hline $\begin{array}{l}\text { FTIR } \\
\text { spectra }\end{array}$ & $\begin{array}{l}\text { OH-related } \\
\text { mineral features } \\
\text { and/or single } \\
3309 \mathrm{~cm}^{-1} \text { peak } \\
\text { are usually } \\
\text { present }\end{array}$ & $\begin{array}{l}\text { OH-related } \\
\text { mineral features } \\
\text { and/or single } \\
3309 \mathrm{~cm}^{-1} \text { peak } \\
\text { are usually } \\
\text { present; } 3161 \\
\mathrm{~cm}^{-1} \text { peak may } \\
\text { be observed }\end{array}$ & $\begin{array}{l}\text { OH-related } \\
\text { mineral features } \\
\text { and/or single } \\
3309 \mathrm{~cm}^{-1} \text { peak } \\
\text { are usually } \\
\text { present; } 3161 \\
\mathrm{~cm}^{-1} \text { peak may } \\
\text { be observed }\end{array}$ & $\begin{array}{l}\text { OH-related } \\
\text { mineral features } \\
\text { and/or single } \\
3309 \mathrm{~cm}^{-1} \text { peak } \\
\text { are usually } \\
\text { present; } 3161 \\
\mathrm{~cm}^{-1} \text { peak may } \\
\text { be observed }\end{array}$ & $\begin{array}{l}\text { OH-related } \\
\text { mineral features } \\
\text { and/or single } \\
3309 \mathrm{~cm}^{-1} \text { peak } \\
\text { are usually } \\
\text { present }\end{array}$ & $\begin{array}{l}\text { OH-related } \\
\text { mineral features } \\
\text { and/or single } \\
3309 \mathrm{~cm}^{-1} \text { peak } \\
\text { are usually } \\
\text { present; } 3161 \\
\mathrm{~cm}^{-1} \text { peak may } \\
\text { be observed }\end{array}$ \\
\hline UV-Vis-NIR & \multicolumn{6}{|c|}{$\begin{array}{l}\text { Fe-related absorption peaks at } 330,377,388 \text {, and } 450 \mathrm{~nm} \text { and } \mathrm{Fe}^{2+}-\mathrm{Ti}^{4+} \text { intervalence charge transfer broad band } \\
\text { centered at } 580 \mathrm{~nm} \text { in the o-ray spectrum. }\end{array}$} \\
\hline spectra & \multicolumn{6}{|c|}{$\begin{array}{l}\text { A broad band centered at } 880 \mathrm{~nm} \text { in the o-ray spectrum can be observed in relatively high-Fe sapphires (this study } \\
\text { and Kan-Nyunt et al., 2013). }\end{array}$} \\
\hline
\end{tabular}

inclusion-free and the cloudy areas. Significant amounts of $\mathrm{Ga}$, typically observed in natural corundum, were also detected in all samples in this study. Apart from those six elements, some other elements, including $\mathrm{Be}, \mathrm{Zr}, \mathrm{Nb}, \mathrm{Sn}, \mathrm{Hf}, \mathrm{Ta}, \mathrm{W}$, and $\mathrm{Th}$, are sometimes present with very low concentrations when analyzed on areas containing particles. Traces of Be can be present in natural untreated sapphires in cloudy areas with a high particle density, and it is frequently associated with $\mathrm{Nb}, \mathrm{Ta}$, light rare earth elements, and/or Th (Shen et al., 2007; Lu and Shen, 2011). In the studied samples, the concentrations of natural Be range from about $<0.5$ to $2.6 \mathrm{ppma}$; $\mathrm{Zr}$, $\mathrm{Nb}, \mathrm{Sn}, \mathrm{Hf}, \mathrm{Ta}, \mathrm{W}$, and Th are generally below detection limits, and they can be measured in quantities of up to 0.5 ppma $\mathrm{Zr}, 0.8$ ppma $\mathrm{Nb}, 7$ ppma $\mathrm{Sn}, 0.02$ ppma Hf, 4 ppma Ta, 9 ppma W, and 0.5 ppma Th.
Trace element concentration distributions in Mogok sapphires from different regions are shown in figures 27 and 28 for Fe and Cr, respectively. Samples from the North, Northeast, East, and Northwest frequently had relatively high Fe content compared to those from the West and Far West areas (figure 27). All regions generally showed little to no Cr concentrations (figure 28), which corresponds with the lack of fluorescence generally observed in the samples (figure 13).

Mogok sapphires are part of the metamorphic group, which also includes Sri Lanka, Madagascar, and Kashmir, as well as some lesser-known sources. Comparing trace element chemistry of Mogok sapphires with the other two major deposits (Sri Lanka and Madagascar) reveals a significant overlap between these sources (figure 29). In some cases, trace

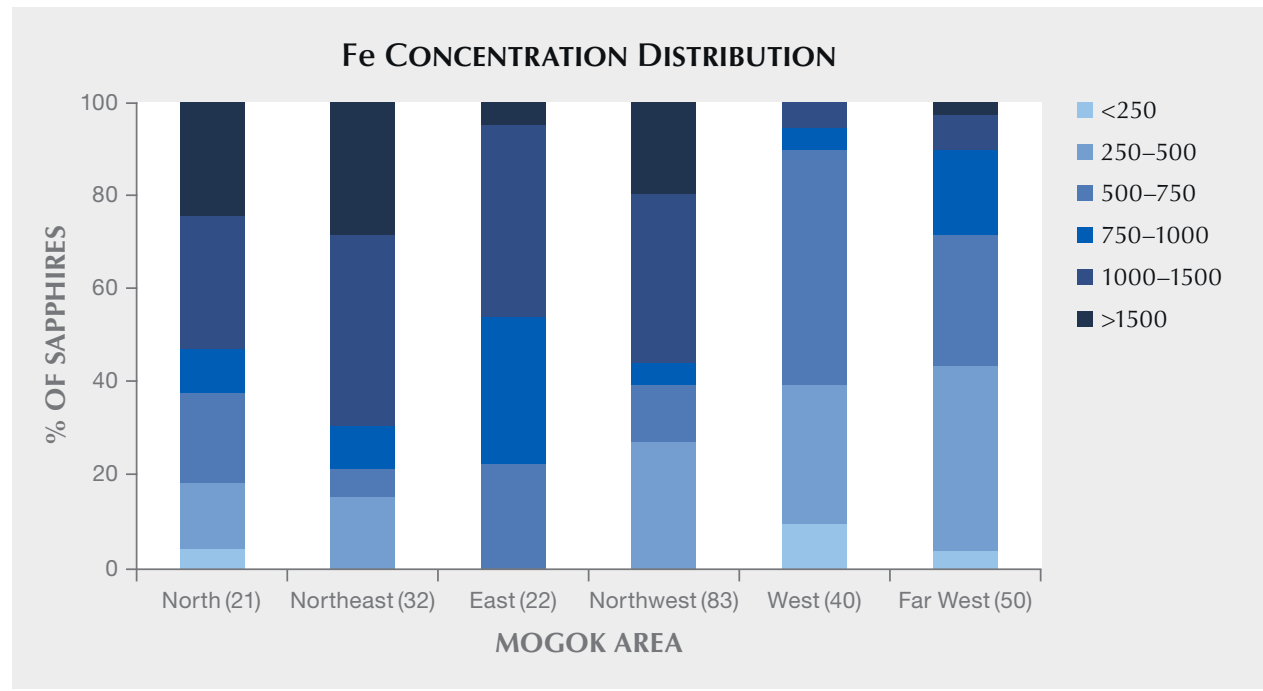

Figure 27. The Fe concentration distribution (in ppma) in Mogok sapphires in this study, separated by region. The sapphires from each region show relatively high Fe concentrations in general. The numbers in parentheses represent the number of samples from each area. 
TABLE 4. Trace element profiles ${ }^{\mathrm{a}}$ of 248 Mogok blue sapphires in this study.

\begin{tabular}{|c|c|c|c|c|c|c|}
\hline \multirow{2}{*}{ Mogok area } & \multicolumn{6}{|c|}{ Concentration in ppma } \\
\hline & $M g$ & $\mathrm{Ti}$ & $\mathrm{V}$ & $\mathrm{Cr}$ & $\mathrm{Fe}$ & $\mathrm{Ga}$ \\
\hline North (21) & $\begin{array}{c}7-122 \\
(38)\end{array}$ & $\begin{array}{c}12-135 \\
(43)\end{array}$ & $\begin{array}{l}0.3-44 \\
\text { (9) }\end{array}$ & $\begin{array}{c}\mathrm{bdl}^{\mathrm{b}}-204 \\
(14)\end{array}$ & $\begin{array}{c}217-2315 \\
(1068)\end{array}$ & $\begin{array}{c}8-41 \\
(20)\end{array}$ \\
\hline Northeast (32) & $\begin{array}{c}0.6-64 \\
(23)\end{array}$ & $\begin{array}{c}6-79 \\
(28)\end{array}$ & $\begin{array}{c}0.1-17 \\
(4)\end{array}$ & $\begin{array}{c}\text { bdl-106 } \\
\text { (4) }\end{array}$ & $\begin{array}{c}240-2267 \\
(1208)\end{array}$ & $\begin{array}{c}11-51 \\
(26)\end{array}$ \\
\hline East (22) & $\begin{array}{c}11-83 \\
(46)\end{array}$ & $\begin{array}{c}10-82 \\
(38)\end{array}$ & $\begin{array}{c}1.2-3 \\
(2)\end{array}$ & $\begin{array}{c}\text { bdl-10 } \\
(0.4)\end{array}$ & $\begin{array}{c}599-1566 \\
(947)\end{array}$ & $\begin{array}{c}6-26 \\
(15)\end{array}$ \\
\hline Northwest (83) & $\begin{array}{c}5-105 \\
(25)\end{array}$ & $\begin{array}{c}6-113 \\
(30)\end{array}$ & $\begin{array}{c}\text { bdl-44 } \\
\text { (2) }\end{array}$ & $\begin{array}{c}\text { bdl-153 } \\
\text { (2) }\end{array}$ & $\begin{array}{c}305-2344 \\
(1101)\end{array}$ & $\begin{array}{c}5-82 \\
(27)\end{array}$ \\
\hline West (40) & $\begin{array}{c}1.1-95 \\
(33)\end{array}$ & $\begin{array}{c}7-111 \\
(39)\end{array}$ & $\begin{array}{l}0.9-25 \\
(7)\end{array}$ & $\begin{array}{c}\text { bdl-158 } \\
(17)\end{array}$ & $\begin{array}{c}104-1366 \\
(527)\end{array}$ & $\begin{array}{c}10-56 \\
(23)\end{array}$ \\
\hline Far West (50) & $\begin{array}{c}7-109 \\
(42)\end{array}$ & $\begin{array}{c}14-124 \\
(45)\end{array}$ & $\begin{array}{c}0.5-22 \\
(3)\end{array}$ & $\begin{array}{c}\text { bdl-76 } \\
\text { (2) }\end{array}$ & $\begin{array}{c}101-1848 \\
(616)\end{array}$ & $\begin{array}{c}9-52 \\
(22)\end{array}$ \\
\hline Detection limit & $0.03-0.4$ & $0.07-0.5$ & $0.01-0.04$ & $0.06-0.4$ & $0.8-5$ & $0.01-0.02$ \\
\hline \multirow{2}{*}{ Mogok area } & \multicolumn{6}{|c|}{ Concentration in ppmw } \\
\hline & $M g$ & $\mathrm{Ti}$ & $\mathrm{v}$ & $\mathrm{Cr}$ & $\mathrm{Fe}$ & Ga \\
\hline North (21) & $\begin{array}{c}8-145 \\
(45)\end{array}$ & $\begin{array}{c}28-137 \\
(101)\end{array}$ & $\begin{array}{c}0.7-110 \\
(22)\end{array}$ & $\begin{array}{c}\text { bdl-520 } \\
(37)\end{array}$ & $\begin{array}{c}594-6340 \\
(2925)\end{array}$ & $\begin{array}{c}27-140 \\
(68)\end{array}$ \\
\hline Northeast (32) & $\begin{array}{c}0.7-76 \\
(27)\end{array}$ & $\begin{array}{c}14-185 \\
(65)\end{array}$ & $\begin{array}{c}0.2-42 \\
(10)\end{array}$ & $\begin{array}{c}\text { bdl-270 } \\
\quad(11)\end{array}$ & $\begin{array}{c}657-6209 \\
(3308)\end{array}$ & $\begin{array}{c}37-174 \\
(89)\end{array}$ \\
\hline East (22) & $\begin{array}{c}13-99 \\
(55)\end{array}$ & $\begin{array}{c}\text { 24-193 } \\
(89)\end{array}$ & $\begin{array}{c}3-7 \\
(5)\end{array}$ & $\begin{array}{l}\text { bdl-25 } \\
\text { (1) }\end{array}$ & $\begin{array}{c}1640-4289 \\
(2594)\end{array}$ & $\begin{array}{c}20-89 \\
(51)\end{array}$ \\
\hline Northwest (83) & $\begin{array}{c}6-125 \\
(30)\end{array}$ & $\begin{array}{c}14-265 \\
(70)\end{array}$ & $\begin{array}{c}\text { bdl-1 } \\
\text { (4) }\end{array}$ & $\begin{array}{c}\text { bdl }-390 \\
\text { (5) }\end{array}$ & $\begin{array}{c}835-6420 \\
(3015)\end{array}$ & $\begin{array}{c}17-280 \\
(92)\end{array}$ \\
\hline West (40) & $\begin{array}{c}1.3-113 \\
(39)\end{array}$ & $\begin{array}{c}16-260 \\
(92)\end{array}$ & $\begin{array}{c}2-62 \\
(17)\end{array}$ & $\begin{array}{c}\text { bdl-403 } \\
(44)\end{array}$ & $\begin{array}{c}284-3741 \\
(1443)\end{array}$ & $\begin{array}{c}34-191 \\
(78)\end{array}$ \\
\hline Far West (50) & $\begin{array}{c}8-130 \\
(50)\end{array}$ & $\begin{array}{c}33-290 \\
(105)\end{array}$ & $\begin{array}{c}1-55 \\
(7)\end{array}$ & $\begin{array}{c}\text { bdl-194 } \\
\text { (5) }\end{array}$ & $\begin{array}{c}277-5061 \\
(1687)\end{array}$ & $\begin{array}{c}30-178 \\
(75)\end{array}$ \\
\hline Detection limit & $0.04-0.5$ & $0.2-1.2$ & $0.02-0.1$ & $0.2-1$ & $2-14$ & $0.03-0.07$ \\
\hline
\end{tabular}

element profiles can support reliable origin determination, but this type of data is seldom conclusive, even after advanced statistical data analysis. Origin determination of metamorphic sapphires still relies heavily on the inclusion scene (see Palke et al., 2019).

\section{CONCLUSIONS}

Mogok is among the classic and most coveted sources of sapphires, which means their properties have been studied for ages. This article attempts to summarize the characteristics of these magnificent blue gems based on samples collected by GIA field gemologists during more than 10 expeditions to the Mogok area in Myanmar.
The geology of the Mogok sapphire deposits is still not well understood. Still, in recent years many studies on the geology of Mogok and the overall genetic processes of sapphires are rapidly leading to new insights into the formation of gem-quality corundum mineralization.

A detailed gemological study showed that blue sapphires from Mogok can vary from very pale to very saturated blue colors (figure 30). While most of the stones are inert under UV light, some show red fluorescence related to trace amounts of chromium, and a small fraction show zoned orange fluorescence linked to trapped holes in the corundum structure. 


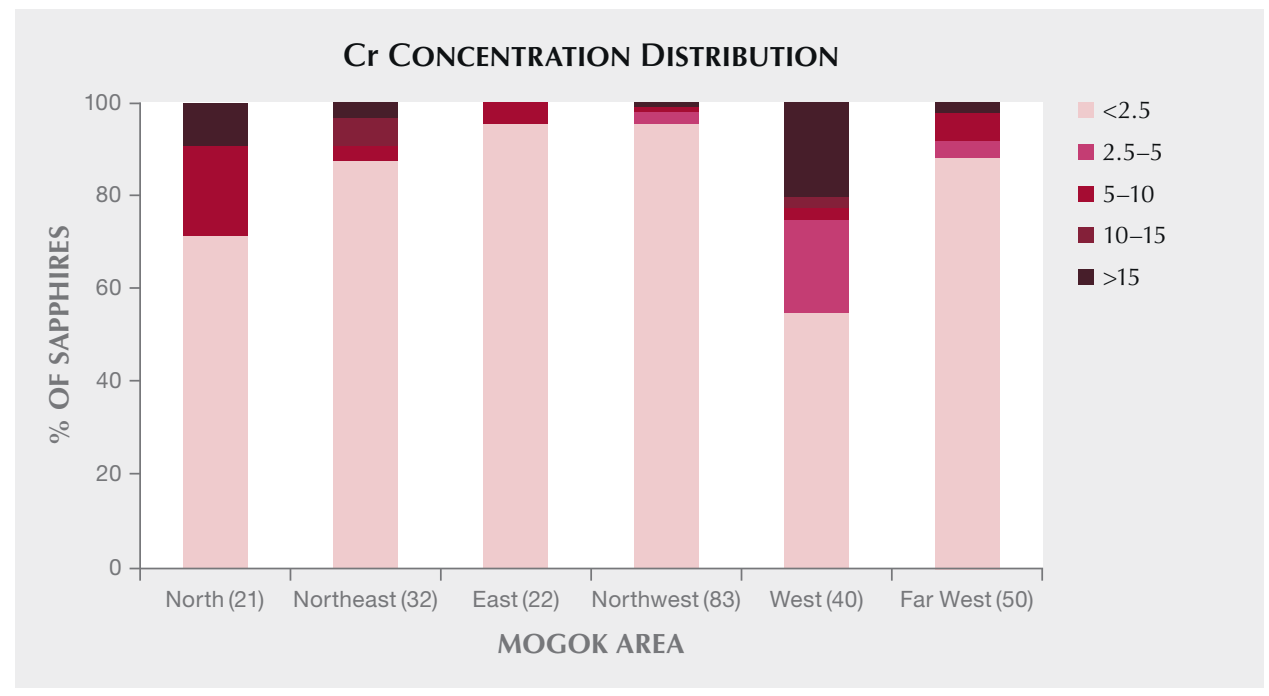

Figure 28. The Cr concentration distribution (in ppma) in Mogok sapphires in this study, separated by region. The sapphires from each region generally have no to relatively low Cr concentrations. The numbers in parentheses represent the number of samples from each area.

Inclusion scenes are similar in sapphires from different regions of the Mogok Valley, with silk in many forms being the main internal feature. Although crystal inclusions are relatively uncommon, mica and feldspar are most commonly encountered. A variety of other minerals were also detected, but they were much rarer. Scapolite is one of those rare inclusions, and this study is the first to report its presence in Mogok blue sapphires. The crystal in- clusions are not conclusive for determining geographic origin. The appearance of silk, twin planes, and fingerprints can indicate the Burmese origin of a sapphire.

Color zoning was observed in only $10 \%$ of the samples. Burmese sapphires show a very diffuse transition from blue to colorless zones. Only a few samples in our study showed some sharp blue-colorless color zoning.

Figure 29. Trace element plots of the studied Mogok sapphires and other metamorphic sources (Sri Lanka and Madagascar) from the GIA field gemology reference collection showing considerable overlap.

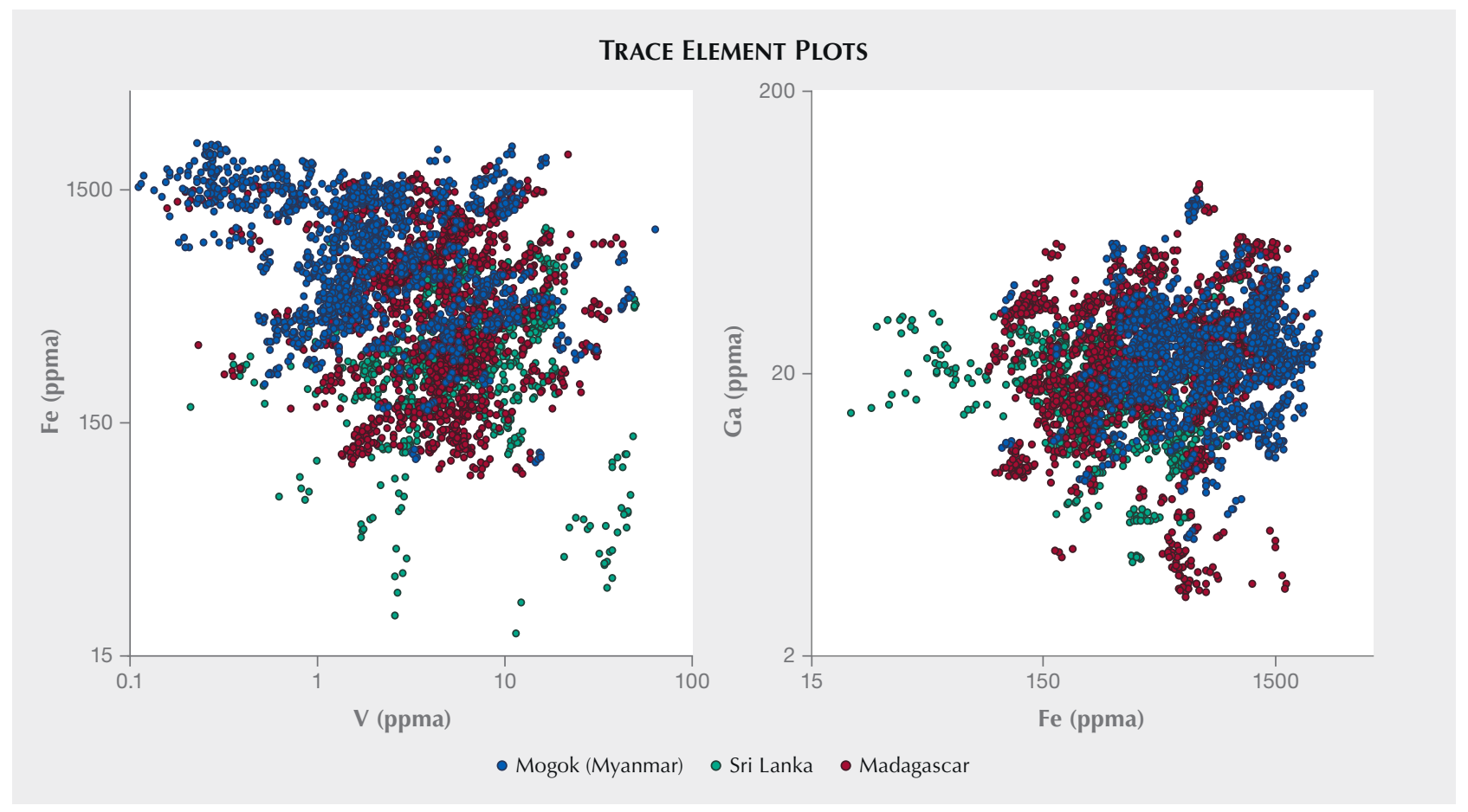




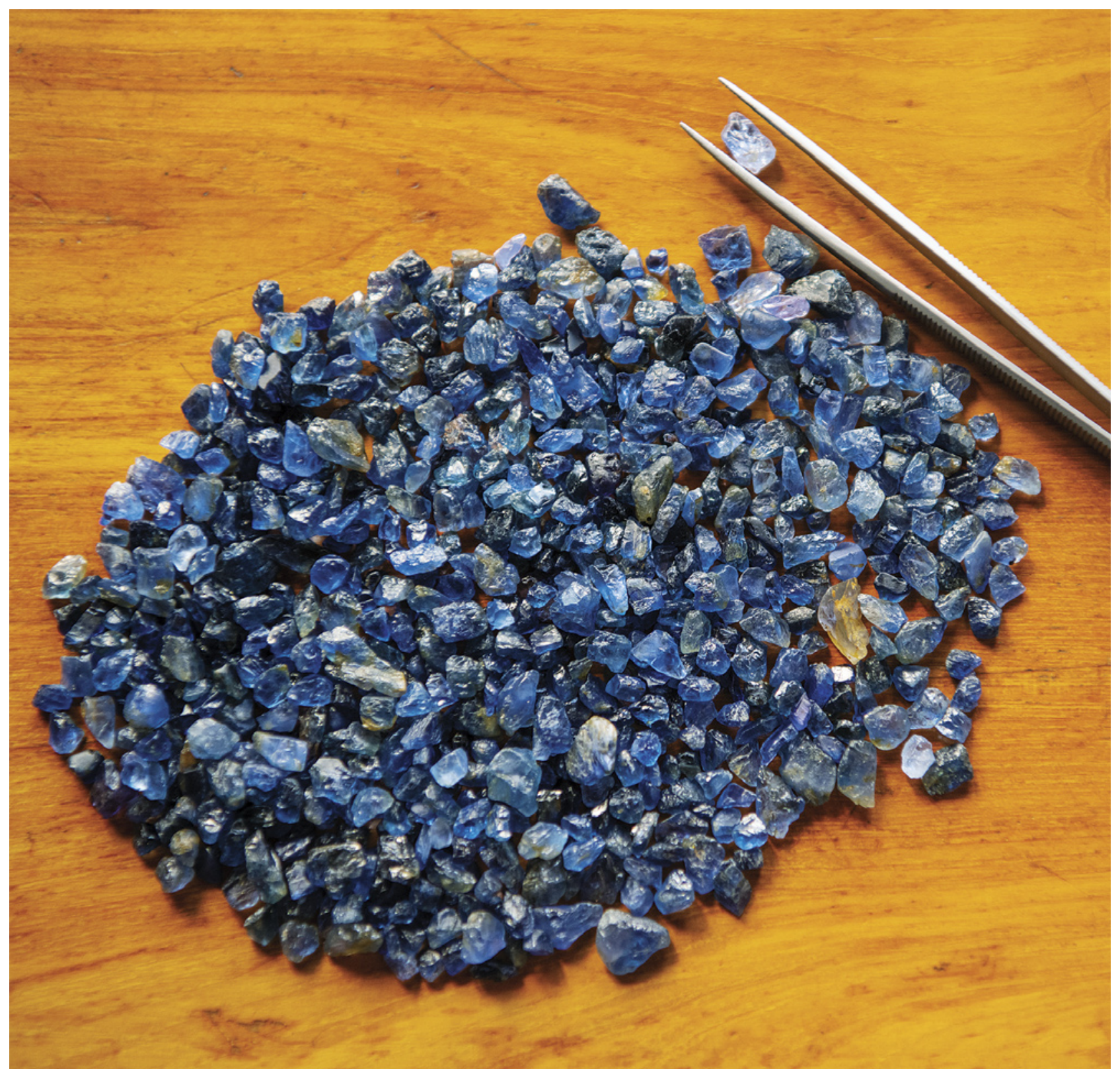

Figure 30. This parcel of sapphire rough was examined at a dealer's office in Mogok, Myanmar. Photo by Robert Weldon/GIA.

FTIR spectra are typically dominated by mineral features such as kaolinite and gibbsite. UV-Vis-NIR spectra are dominated by bands related to $\mathrm{Fe}^{2+}-\mathrm{Ti}^{4+}$ intervalence charge transfer and other peaks associated with $\mathrm{Fe}^{3+}$ species. In some stones with higher $\mathrm{Fe}$ concentrations, a small broad band is present at 880 $\mathrm{nm}$, which is not commonly associated with untreated metamorphic sapphires.

Trace element chemistry revealed a wide range of Fe concentrations, although the maximum values were much higher in the sapphires from the eastern part of Mogok than those from western Mogok. Chromium concentrations were very low, and stones with an increased $\mathrm{Cr}$ content typically showed a slightly altered color (violetish tint) and red fluorescence. Natural beryllium can be detected in Burmese sapphires, but it is always measured in particle-rich areas. 
ABOUT THE AUTHORS

Dr. Soonthorntantikul is a research scientist, Ms. Atikarnsakul is a staff gemologist, and Mr. Vertriest is manager of field gemology, at GIA's Bangkok laboratory.

\section{ACKNOWLEDGMENTS}

The authors would like to thank all the miners and contacts that helped us during the numerous field visits, especially Aung Naing Jordan, Kyaw Thu, and May Tin Zaw Win. We would also like to extend our thanks to GIA's field gemology department for their year-long efforts in collecting and documenting the samples used for this study, especially Vincent Pardieu, Victoria Raynaud-Flattot, Sasithorn Engniwat, and Suwasan Wongchacree. The GIA colored stone research team assisted in collecting some of the data over the past years. We are grateful to Supharart Sangsawong, Vararut Weeramonkhonlert, Nattida Ng-Pooresatien, Titapa Tanawansombat, and Charuwan Khowpong for the collection of inclusion photomicrographs as well as spectroscopic data and trace element chemistry compositions. We would also like to thank Dr. Aaron Palke, Shane McClure, Sudarat Saeseaw, and Nathan Renfro for numerous discussions on Burmese sapphires. Anonymous peer reviewers are also thanked for providing helpful comments and suggestions.

\section{REFERENCES}

d'Amato P.G. (1833) A short description of the mines of precious stones in the district of Kyatpyin, in the Kingdom of Ava. Journal of the Asiatic Society of Bengal, Vol. 2, pp. 75-76.

Atikarnsakul U., Vertriest W., Soonthorntantikul W. (2018) Characterization of blue sapphires from the Mogok Stone Tract, Mandalay region, Burma (Myanmar). GIA Research News, https://www.gia.edu/ongoing-research/characterization-bluesapphires-from-mogok-stone-tract-mandalay-region-burmamyanmar

Beran A., Rossman G.R. (2006) OH in naturally occurring corundum. European Journal of Mineralogy, Vol. 18, No. 4, pp. 441447, http://dx.doi.org/10.1127/0935-1221/2006/0018-0441

Brown J.C. (1927) Gem mining in the Mogok Stone Tract of Upper Burma from the annexation to the present time (confidential report). Office of the Superintendent, Rangoon, Burma.

Brown J.C., Dey A.K. (1955) India's Mineral Wealth. Oxford University Press, Bombay.

Dubinsky E.V., Stone-Sundberg J., Emmett J.L. (2020) A quantitative description of the causes of color in corundum. $G \oplus G$, Vol. 56, No. 1, pp. 2-28, http://dx.doi.org/10.5741/GEMS.56.1.2

Gardiner N.J., Robb L.J., Searle M.P. (2014) The metallogenic provinces of Myanmar. Applied Earth Science, Vol. 123, No. 1, pp. 25-38, http://dx.doi.org/10.1179/1743275814Y.0000000049

Gardiner N.J., Robb L.J., Morley C.K., Searle M.P., Cawood P.A., Whitehouse M.J., Kirkland C.L., Roberts N.M.W., Myint T.A. (2016) The tectonic and metallogenic framework of Myanmar: A Tethyan mineral system. Ore Geology Reviews, Vol. 79, pp. 26-45, http://dx.doi.org/10.1016/j.oregeorev.2016.04.024

Garnier V., Giuliani G., Ohnenstetter D., Fallick A.E., Dubessy J., Banks D., Vihn H.Q., Lhomme T., Maluski H., Pêcher A., Bakhsh K.A., Long P.V., Trinh P.T., Schwarz D. (2008) Marblehosted ruby deposits from Central and Southeast Asia: Towards a new genetic model. Ore Geology Reviews, Vol. 34, No. 1-2, pp. 169-191, http://dx.doi.org/10.1016/j.oregeorev.2008.03.003

Giuliani G., Ohnenstetter D., Fallick A., Groat L., Fagan A.J. (2014) Chapter 2: The geology and genesis of gem corundum deposits. In L. Groat, Ed., Geology of Gem Deposits, 2nd ed. Mineralogical Association of Canada, Tucson, Arizona.

Gübelin E.J., Koivula J.I. (2008) Photoatlas of Inclusions in Gemstones, Vol. 3, Opinio Verlag Publishers, Basel, Switzerland, pp. 188-193.

Halford-Watkins J.F. (1935) Burma sapphires-locations and characteristics. The Gemmologist, Vol. 5, No. 52, pp. 89-98.

Hughes R.W., Win U.H. (1995) Burmese sapphire giants. Journal of Gemmology, Vol. 24, No. 8, pp. 551-561.

Hughes R.W., Manorotkul W., Hughes E.B. (2017) Ruby ↔) Sapphire: A Gemologist's Guide, 1st ed., RWH Publishing/Lotus Publishing, Thailand.
Iyer L.A.N. (1953) The geology and gem-stones of the Mogok Stone Tract, Burma. Memoirs, Geological Survey of India, Vol. 82, pp. 8-100.

Kammerling R.C., Scarratt K., Bosshart G., Jobbins E.A., Kane R.E., Gübelin E.J., Levinson A.A. (1994) Myanmar and its gems - an update. Journal of Gemmology, Vol. 24, No. 1, pp. 3-40.

Kan-Nyunt H.-P., Karampelas S., Link K., Thu K., Kiefert L., Hardy P. (2013) Blue sapphires from the Baw Mar mine in Mogok. GeG, Vol. 49, No. 4, pp. 223-245 http://dx.doi.org/10.5741/GEMS.49.4.223

Lu R., Shen A. (2011) Lab Notes: Unusually high beryllium in three blue sapphires. Ge G, Vol. 47, No. 3, pp. 232-233.

Luard C.E. (1926-1927) Travels of Fray Sebastien Manrique: 1629 1643. Hakluyt Society, Oxford, UK.

Notari F., Fritsch E., Caplan C., Hainschwang T. (2018) "Boehmite needles" in corundum are rose channels. $G \uplus G$, Vol. 54, No. 3, pp. 257

Oo T.K. (2011) Prediction of exploration target areas for gem deposits in Mogok Stone Tract, northern Myanmar by integrating remote sensing and geoscience data. In K. Satake and C-H. Lo, Eds., Advances in Geosciences, Vol. 26. World Scientific Publishing Co., Singapore, pp. 181-198.

Palke A.C., Saeseaw S., Renfro N.D., Sun Z., McClure S.F. (2019) Geographic origin determination of blue sapphire. $G \uplus G$, Vol 55, No. 4, pp. 536-579, http://dx.doi.org/10.5741/GEMS.55.4.536

Penzer N.M. (1937) The Most Noble and Famous Travels of Marco Polo, Together with the Travels of Nicolò de' Conti, 2nd ed., from the translation by J. Frampton. Adam \& Charles Black, London.

Peucat J.J., Ruffault P., Fritsch E., Bouhnik-Le Coz M., Simonet C., Lasnier B. (2007) Ga/Mg ratio as a new geochemical tool to differentiate magmatic from metamorphic blue sapphires. Lithos, Vol. 98, No. 1-4, pp. 261-274, http://dx.doi.org/10.1016/j.lithos.2007.05.001

Raynaud V., Vertriest W. (2017) Micro-World: Negative crystals in sapphires, GÆ G, Vol. 53, No. 1, pp. 107-108.

Rupasinghe M.S., Dissanayake C.B. (1985) Charnockites and the genesis of gem minerals. Chemical Geology, Vol. 53, No. 1-2, pp. 1-16, http://dx.doi.org/10.1016/0009-2541/85|90015-4

Saengbuangamlam S., Narudeesombat N., Atichat W., PisuthaArnond V., Sun T.T., Leelawatanasuk T., Bupparaenoo P. (2016) Burmese sapphire from Mogok: Its inclusions and country of origin determination, GIT Technical Articles, www.git.or.th/eng/testing_center_en/lab_notes_en/glab_en/ 2016/11/B36-1.pdf

Searle M., Noble S., Cottle J., Waters D., Mitchell A., Hlaing T. Horstwood M. (2007) Tectonic evolution of the Mogok metamorphic belt, Burma (Myanmar) constrained by U-Th-Pb dating of metamorphic and magmatic rocks. Tectonics, Vol. 26, 
No. 3, http://dx.doi.org/10.1029/2006TC002083

Searle M.P., Morley C.K., Waters D.J., Gardiner N.J., Htun U.K., Nu T.T., Robb L.J. (2017) Chapter 12: Tectonic and metamorphic evolution of the Mogok metamorphic and jade mines belts and ophiolitic terranes of Burma (Myanmar). Geological Society, London, Memoirs, Vol. 48, No. 1, pp. 261-293, http://dx.doi.org/10.1144/M48.12

Searle M.P., Garber J.M., Hacker B.R., Htun K., Gardiner N.J., Waters D.J., Robb L.J. (2020) Timing of syenite-charnockite magmatism and ruby and sapphire metamorphism in the Mogok Valley Region, Myanmar. Tectonics, Vol. 39, No. 3, http://dx.doi.org/10.1029/2019TC005998

Shen A., McClure S., Breeding M., Scarratt K., Wang W., Smith C., Shigley J. (2007) From the GIA Laboratory: Beryllium in corundum: The consequences for blue sapphire. GIA Insider, Vol. 9, No. 2, Jan 26, 2007.

Smith C.P. (1995) A contribution to understanding the infrared spectra of rubies from Mong Hsu, Myanmar. Journal of Gemmology, Vol. 24, No. 5, pp. 321-335.

(2010) Inside sapphires. Rapaport Diamond Report, pp. $123-132$

Smith C.P., Van der Bogert C. (2006) Infrared spectra of gem corundum. GÆG, Vol. 42, No. 3, pp. 92-93.

Smith G.F.H. (1972) Gemstones. Chapman and Hall, London.

Soonthorntantikul W., Vertriest W., Raynaud-Flattot V.L., Sangsawong S., Atikarnsakul U., Khowpong C., Weeramongkhonlert V., Pardieu V. (2017) An in-depth gemological study of blue sapphires from the Baw Mar mine (Mogok, Myanmar). GIA Research News, https://www.gia.edu/gia-news-research/bluesapphires-baw-mar-mine-mogok-myanmar
Stone-Sundberg J., Thomas T., Sun Z., Guan Y., Cole Z., Equall R., Emmett J.L. (2017) Accurate reporting of key trace elements in ruby and sapphire using matrix-matched standards, $G \uplus G$, Vol. 53, No. 4, pp. 438-451, http://dx.doi.org/10.5741/GEMS.53.4.438

Streeter E.W. (1892) Precious Stones and Gems, 5th ed. Bell, London.

Temple R.C., Ed. (1928) The Itinerary of Ludovico di Varthema of Bologna from 1502 to 1508. Argonaut Press, London.

Themelis T. (2008) Gems $\nrightarrow$ ) Mines of Mogok. Publ. by the author, Bangkok.

Thomas T. (2009) Corundum c-axis device for sample preparation. GIA Research News, www.gia.edu/ongoingresearch/corundum-c-axis-device-for-sample-preparation

Thu K. (2007) The Igneous Rocks of the Mogok Stone Tract: Their Distributions, Petrography, Petrochemistry, Sequence, Geochronology and Economic Geology. University of Yangon, Myanmar.

Turnier R., Harlow G.E. (2017) Syenite-hosted sapphires: What's going on. Fourteenth Annual Sinkankas Symposium-Sapphire. Pala International Inc., pp. 22-33.

Vertriest W., Palke A.C., Renfro N.D. (2019) Field gemology: Building a research collection and understanding the development of gem deposits. Ge G, Vol. 55, No. 4, pp. 490-511, http://dx.doi.org/10.5741/GEMS.55.4.490

Zahirovic S., Müller R.D., Seton M., Flament N., Gurnis M., Whittaker J. (2012) Insights on the kinematics of the IndiaEurasia collision from global geodynamic models. Geochemistry, Geophysics, Geosystems, Vol. 13, No. 4, http://dx.doi.org/10.1029/2011GC003883

\section{For online access to all issues of GEMS \& GEMOLOGY from 1934 to the present, visit:}

